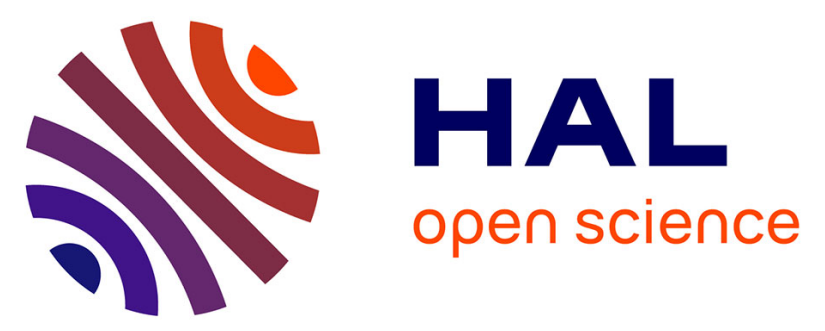

\title{
Chemical Heterogeneities within the Disordered Mineral domains of Aragonite Platelets in nacre from the European Abalone Haliotis tuberculata
}

Widad Ajili, Guillaume Laurent, Nicolas F Menguy, Axel Gansmuller, Sylvain Huchette, Stéphanie Auzoux-Bordenave, Nadine Nassif, Thierry Azaïs

\section{To cite this version:}

Widad Ajili, Guillaume Laurent, Nicolas F Menguy, Axel Gansmuller, Sylvain Huchette, et al.. Chemical Heterogeneities within the Disordered Mineral domains of Aragonite Platelets in nacre from the European Abalone Haliotis tuberculata. Journal of Physical Chemistry C, 2020, 124 (26), pp.1411814130. 10.1021/acs.jpcc.0c00280 . hal-03013898

\section{HAL Id: hal-03013898 https://hal.sorbonne-universite.fr/hal-03013898}

Submitted on 19 Nov 2020

HAL is a multi-disciplinary open access archive for the deposit and dissemination of scientific research documents, whether they are published or not. The documents may come from teaching and research institutions in France or abroad, or from public or private research centers.
L'archive ouverte pluridisciplinaire HAL, est destinée au dépôt et à la diffusion de documents scientifiques de niveau recherche, publiés ou non, émanant des établissements d'enseignement et de recherche français ou étrangers, des laboratoires publics ou privés. 


\section{Chemical Heterogeneities within the Disordered Mineral}

\section{domains of Aragonite Platelets in nacre from the European}

\section{Abalone Haliotis tuberculata}

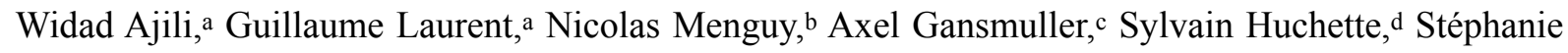
Auzoux-Bordenave, e Nadine Nassifa and Thierry Azais ${ }^{a} *$

a Sorbonne Université, CNRS, Collège de France, Laboratoire de Chimie de la Matière Condensée de Paris (LCMCP), 4, place Jussieu, F-75005, Paris, France.

b Sorbonne Université, UMR CNRS 7590, Muséum National d'Histoire Naturelle, IRD, Institut de Minéralogie, de Physique des Matériaux et de Cosmochimie, IMPMC, F-75005 Paris, France.

c CRM2 UMR 7036 CNRS-Université de Lorraine, Bvd. des Aiguillettes, BP 70239, Vandoeuvre-lèsNancy F-54506, France

¿ Ecloserie France Haliotis, Kérazan, 29880 Plouguerneau, France

e UMR Biologie des Organismes et Ecosystèmes Aquatiques (BOREA), MNHN/CNRS/IRD/Sorbonne Université, Muséum national d'Histoire naturelle, Station marine de Concarneau, 29900 Concarneau, France.

* corresponding author : thierry.azais@upmc.fr 


\section{Abstract}

Since the observation in 2005 of a disordered mineral layer at the surface of aragonite platelets in abalone Haliotis laevigata nacre, the model of the organo-mineral interface in such biomineralized tissue has been challenged. As a direct interaction between the aragonite crystalline core and the organic matrix is no longer appropriate to describe such interface, a structural description of the disordered mineral domains at the atomic level is a key for a comprehensive view of nacre ultrastructure. Here, we use European abalone Haliotis tuberculata as a model to investigate aragonite nacre through high-resolution transmission electron microscopy (HR-TEM) and multinuclear solid state nuclear magnetic resonance (ssNMR). The presence of a disordered domain around aragonite crystals is shown through HR-TEM observations similarly to Haliotis laevigata. The structure and the ionic composition of the disordered mineral environments of Haliotis tuberculata nacre are investigated through ${ }^{1} \mathrm{H},{ }^{13} \mathrm{C},{ }^{43} \mathrm{Ca}$ and ${ }^{23} \mathrm{Na}$ ssNMR. Interestingly, we demonstrate that the disordered mineral domains in nacre seem to be heterogeneous in terms of structure and chemical composition and do not match with amorphous calcium carbonate stricto sensu. At least three different carbonates species are evidenced, including $\mathrm{CO}_{3}^{2-}$ and $\mathrm{HCO}_{3}^{-}$present in the same mineral domain and closely associated to rigid $\mathrm{H}_{2} \mathrm{O}$ molecules. The local disorder around these ions is found to be inhomogeneous as some $\mathrm{CO}_{3}{ }^{2-}$ possess an aragonitic environment and are rather ordered (according to the position and line width of their ${ }^{13} \mathrm{C}$ resonance) whereas, in opposition, the chemical environment around $\mathrm{HCO}_{3}$ - is highly distributed. The analysis of potential cations as counter-ions revealed the presence of disordered $\mathrm{Ca}^{2+}$ and the presence of $\mathrm{Na}^{+}$closely associated to $\mathrm{HCO}_{3}$. Based on these structural data, we propose an atomic-level model for the disordered domains in abalone (H.tuberculata) nacre where the protonation level of carbonate ions, the proportion of sodium ions and the local disorder are increasing from the inner to the outer part of disordered domains. These results give an unprecedented structural view at the atomic scale of such disordered mineral domains in nacre aragonite tablets. 


\section{Introduction}

The shell of marine mollusks is a composite material composed of calcium carbonate, $\mathrm{CaCO}_{3}$, intimately associated with an organic matrix secreted by the mantle epithelial cells ${ }^{1,2,3}$. In abalone shell, three distinct layers are typically observed: (i) an outer organic layer (periostracum), (ii) an intermediate prismatic or spherulitic layer and (iii) an internal nacreous layer ${ }^{1,4,5,6}$. The mineral formation is controlled by specific macromolecules secreted by the mantle $7,8,9,10,11$. This mineral phase represents about $95 \mathrm{w} \%$ of the natural composite material12; the remaining $5 \mathrm{w} \%$ being the organic matrix.

The mineral phase in nacre crystallized in the form of aragonite tablets and their threedimensional (3D) organization varies from one species to another, forming brick wall-like disposition for bivalves or a columnar structure in the case of gastropods ${ }^{13,14,15}$. Because of its lamellar architecture and hybrid composition, nacre exhibits remarkable mechanical properties especially in terms of fracture resistance which can be three thousand times higher compared to a single crystal of aragonite. ${ }^{16}$

The resulting confluent aragonite tablets are characterized by a diameter ranging from 5 to $10 \mu \mathrm{m}$ and a thickness of about $0.5 \mu \mathrm{m}$. A thin $(\sim 20 \mathrm{~nm}$ thick) organic matrix layer composed of proteins, polysaccharides and presumably lipids surrounds the mineral tablets. $17,18 \cdot 19,20$

The polysaccharide fraction is made of $\beta$-chitin, sulphated and acidic polysaccharides. 14,20,21,22,23,24 The second organic fraction is composed of two different types of proteins: silk and acidic proteins. Silk proteins are the major protein fraction and are present in a hydrogel-like state within $\beta$ chitin layer. ${ }^{25}$ This fraction is proposed to be involved in nacre formation by controlling the growth in thickness of aragonite tablets. ${ }^{25}$ On the other hand, the so-called "acidic proteins" are soluble in acidic extracting-solvent and are particularly rich in aspartic amino acid. They are proposed to be involved in calcium carbonate nucleation and in the selection of the aragonite polymorph by inhibiting calcite nucleation.9,10,26 Overall, nacre formation is described to begin with the set-up of the organic layers acting as a scaffold for the building of the nacreous layers. The mineral phase is described to grow afterwards in-between these layers.

Concerning the mineral fraction, mature aragonite tablets are described as single crystals as they display a unique electron diffraction pattern 27 and an homogeneous crystalline network through 
HR-TEM observations. ${ }^{28}$ Moreover, aragonite crystals are described as co-oriented along their $c$-axis parallel to the platelets stacking $29,30,31,32$ even if recent findings highlighted some specific mismatch in the co-orientation. 33 If no consensus appears yet, different crystallization processes have been proposed in the literature to explain such organization. ${ }^{29,30,31}$ The heteroepitaxy mechanism was first described and proposed that the organic fraction acts as a template where carboxylic groups are nucleation sites for the calcium ions; the overall matching with the aragonite crystalline lattice. ${ }^{34}$ Later on, the observation of mineral bridges between adjacent tablets leaded to the description of homoepitaxial process for ionic crystals. ${ }^{28,35,36}$ In addition, transmission (TEM) ${ }^{37}$, scanning electronic microscopy (SEM) 25,38,39,40 as well as atomic force microscopy (AFM) ${ }^{41}$ observations revealed that aragonite crystals display a specific arrangement resulting from a possible assembly of colloidal nanoparticles with an average size of 50-100 $\mathrm{nm}$. According to these observations, an alternative mechanism was proposed where calcium carbonate precursors are first deposited as amorphous nanograins that crystallized afterwards. 42

Moreover, it was shown that intra-crystalline organic molecules are entrapped within individual crystallites ${ }^{18,43}$ inducing anisotropic lattice distortions in Perna canaliculus. ${ }^{44}$ Concomitantly, aragonite tablet in nacre was more recently described as mesocrystal with co-oriented nanocrystals diffracting like a single crystal. ${ }^{45}$ According to these various proposed mechanisms, the chemical description of the aragonite platelets surface is essential to understand the set-up of the organo-mineral and the mineral-mineral interface at the molecular scale. Moreover, since aragonite tablets are not perfect single crystals, a local disorder exists at the nanoscopic scale either at the surface or within the crystals. Describing such local disorder at the nanometer scale is also a challenge to understand the formation of such biomineral.

In parallel, a disordered mineral layer at the surface of the aragonite tablets from mature nacre in Haliotis laevigata was evidenced through HR-TEM and ${ }^{13} \mathrm{C}$ ssNMR.46 Such a layer was also observed in forming nacre tablets in Perna viridis. ${ }^{47}$ In fact, the exact chemical nature of this amorphous-like phase is still unclear due to the difficulties in determining the atomic composition although it is often referred to an amorphous calcium carbonate (ACC) layer ${ }^{46,48}$. The role of this layer is also unclear although the presence of a distinct disordered surface mineral layer around the crystalline core of some biominerals appears to be a common feature in vivo in calcified tissues $46,49,50,51$ and for synthetic analogues.52,53 Different attempts are found in the literature to clear 
these issues. More precisely, specific analytical techniques are used to obtain structural information at the atomic level. Solid state NMR appears a key technique in the biomineralization field ${ }^{54,55,56}$. For example, ${ }^{13} \mathrm{C}$ ssNMR was efficient to reveal disordered carbonates in a proton-rich environment in the nacre of Haliotis laevigata that were assigned to the ACC surface layer of aragonite crystals. ${ }^{46}$ Additionally, it was shown that this surface layer contains hydrogen carbonate groups and water molecules presumably at its outer surface. ${ }^{57}$ More recently, the whole aragonitic shell (not only the nacreous part) of Perna canaliculus was studied through multinuclear ssNMR in order to describe the organo-mineral interface. ${ }^{58}$ Different disordered carbonate environments were identified and divided in two categories: "exposed carbonate", located at the surface of aragonite particles in interaction with the organics molecules, and "buried carbonate" defects within the mineral bulk in the aragonite tablet surface region. Finally, hyperpolarized ${ }^{13} \mathrm{C}$ solid state NMR experiments have recently evidenced a large amount of exposed bicarbonates in the nacre of Haliotis tuberculata and that these bicarbonates are involved at the organo-mineral interface as close proximities with organic moieties. 59

To progress in the understanding of the above mentioned issues we report in this work, the detailed structural analysis of disordered mineral domains in nacre of the European abalone Haliotis tuberculata, a key model to study the basic mechanisms of shell mineralization. Larval development and shell formation were previously studied showing that the early larval shell is mostly composed of ACC, followed subsequently by the deposition of aragonite in the juvenile and the adult shells. ${ }^{60,61}$ The adult shell of the European abalone is composed of two main aragonite layers (underlying the periostracum), namely the outer sphrerulitic layer and the innermost nacreous layer. The abalone nacre has been largely studied revealing a typical columnar structure, remarkable mechanical properties and potential uses in jewellery and as biomaterial.7,17,62,63,64 To go further, we performed an atomic level analysis of the calcium carbonate disordered domains in Haliotis tuberculata's nacre through HRTEM and multinuclear (including ${ }^{1} \mathrm{H},{ }^{13} \mathrm{C},{ }^{43} \mathrm{Ca}$ and ${ }^{23} \mathrm{Na}$ ) ssNMR in order to localize spatially the disordered mineral environments and identify the ionic composition of such domains. HR-TEM observations of a focused ion beam (FIB) nacre thin cross-section revealed the presence of an outer disordered layer around the aragonite tablets while the ssNMR results evidenced certain structural heterogeneities within the disordered mineral domains. In particular, we highlight the presence of different divalent $\left(\mathrm{CO}_{3}{ }^{2-}\right.$ and $\left.\mathrm{Ca}^{2+}\right)$ as well as monovalent ions $\left(\mathrm{HCO}_{3}{ }^{2-}\right.$ and $\left.\mathrm{Na}^{+}\right)$. In addition, the local 
disorder around these ions is not homogeneous. Therefore, disordered mineral domains in European abalone are chemically and structurally complex and cannot be assigned to an ACC phase stricto sensu. This original data provides new insights to improve our understanding of the organo-mineral interface which is fundamental for the formation of this biological material. 


\section{Experimental section}

\section{Biological material and reference sample synthesis}

One and four years-old European abalone, Haliotis tuberculata, specimens were obtained from France Haliotis farm $\left(48^{\circ} 36^{\prime} 46 \mathrm{~N}, 4^{\circ} 33^{\prime} 30 \mathrm{~W}\right.$; Plouguerneau, France). After dissection, shells measuring between 1 (1-year-old) and $5 \mathrm{~cm}$ (4-years-old) in length were washed with distilled water, dried and stored at room temperature until analysis.

The ACC reference sample was prepared according to the synthesis reported by Jiang et al. ${ }^{65}$. ACC was obtained by mixing calcium chloride $(0.1 \mathrm{M})$ and magnesium chloride hexahydrate $(0.5 \mathrm{M})$. Anhydrous sodium carbonate $(0.1 \mathrm{M})$ was then added rapidly to the mixed solution though mechanical stirring at ambient temperature. The precipitated colloidal phase was filtrated immediately and washed by ethanol. The precipitate was dried in a vacuum desiccator for one day. The amorphous nature of the resulting sample was checked by ${ }^{13} \mathrm{C}$ NMR (see Supporting Information - Fig. S8).

Aragonite reference sample was prepared according to synthesis reported by Matijevic et al. ${ }^{66}$ where $0.25 \mathrm{M}$ of $\mathrm{CaCl}_{2}$ was mixed to ${ }^{13} \mathrm{C}$-labeled Urea $(2.25 \mathrm{M})$. The obtained solid was filtrated using $0,22 \mu \mathrm{m}$ Millipore membranes and rinsed with distilled water. The precipitate was finally dried in a vacuum oven overnight at $90^{\circ} \mathrm{C}$ and then stored in a desiccator.

\section{HR TEM}

Focused Ion Beam (FIB) was performed on the nacre layer from 1 year-old $H$. tuberculata shell using Zeiss Crossbeam Neon40 at IMPMC (Sorbonne Université, Paris). A thin section of approximatively $100 \mathrm{~nm}$ in thickness has been prepared and observed by HR-TEM. The observations were performed on a JEOL-2100F microscope operating at $200 \mathrm{kV}$, equipped with a field emission gun, a JEOL detector with an ultrathin window allowing detection of light elements, and a scanning TEM (STEM) device, which allows Z-contrast imaging in HAADF mode (STEM-HAADF). 


\section{Solid-State NMR}

For the ssNMR analyses, the outer layers (the periostracum and the sphrerulitic layer) from 4years-old $H$. tuberculata shell were removed by sanding in order to obtain only the nacreous layer. Nacre was then manually grinded in an agate mortar and the resulting powder directly packed into a 7 $\mathrm{mm}(\sim 230 \mathrm{mg})$ or a $4 \mathrm{~mm}(\sim 85 \mathrm{mg})$ NMR rotor.

${ }^{13} \mathrm{C}$ solid state NMR spectroscopy experiments were carried out on a Bruker Avance III spectrometer operating at a magnetic field of $7.1 \mathrm{~T}$. The corresponding Larmor frequencies are 300.29 MHz for ${ }^{1} \mathrm{H}$ and $75.51 \mathrm{MHz}$ for ${ }^{13} \mathrm{C}$. Powder samples were packed into $7 \mathrm{~mm}$ zirconia rotors and spun at the magic angle at a frequency $v_{\mathrm{MAS}}=5 \mathrm{kHz}$. Direct acquisition spectrum was recorded with a recycle relay $\mathrm{RD}=2000 \mathrm{~s} .{ }^{1} \mathrm{H}-{ }^{13} \mathrm{C}$ CP MAS experiments were recorded with $\mathrm{RD}=1$ or $10 \mathrm{~s}$. ${ }^{1} \mathrm{H}$-echo- ${ }^{13} \mathrm{C}$ CP MAS experiment (1D and 2D) was performed through the addition of a ${ }^{1} \mathrm{H}$-echo sequence $(\pi / 2-\tau-\tau-\tau)$, before a standard cross polarization sequence. The ${ }^{1} \mathrm{H}$-echo delay $\tau$ corresponds to one rotor period i.e. $0.2 \mathrm{~ms}$. The contact time $\mathrm{t}_{\mathrm{CP}}$ is indicated in the Figure captions. Two dimensional ${ }^{1} \mathrm{H}$-echo-13 $\mathrm{C}$ HetCor experiment was performed through the addition of an evolution period $\left(t_{1}\right)$ after the ${ }^{1} \mathrm{H}$-echo allowing the refocusing of the ${ }^{1} \mathrm{H}$ chemical shift. Two dimensional ${ }^{1} \mathrm{H}-$ echo- ${ }^{13} \mathrm{C}$ HetCor spectrum was recorded using $\mathrm{RD}=10 \mathrm{~s}, \tau=0.2 \mathrm{~ms}$ and 6720 transients for each 32 $\mathrm{t}_{1}$ increment (total experimental time $=24$ days, 21 hours and $20 \mathrm{~min}$ ). Slow MAS rate ${ }^{13} \mathrm{C}$ CP MAS NMR experiments were recorded with $v_{\mathrm{MAS}}=1.5 \mathrm{kHz}$ and $\mathrm{t}_{\mathrm{CP}}=10 \mathrm{~ms}$. The set-up of the HartmannHahn condition was performed directly on the nacre sample in order to maximize the sensitivity.

Crystalline $\mathrm{NaHCO}_{3}(>99.7 \%)$ and isotopically labeled crystalline $\mathrm{Na}_{2}{ }^{13} \mathrm{CO}_{3} \quad(>99.9 \%)$ references have been purchased from Sigma Aldrich. Low MAS experiments were performed on a Bruker NMR Avance III spectrometer operating at $14 \mathrm{~T}\left({ }^{1} \mathrm{H}\right.$ NMR frequency of $\left.600 \mathrm{MHz}\right)$ with a Bruker $4 \mathrm{~mm}$ MAS triple-resonance probe, at MAS frequency $v_{\mathrm{MAS}}=2 \mathrm{kHz}$. For $\mathrm{Na}_{2}{ }^{13} \mathrm{CO}_{3},{ }^{13} \mathrm{C}$ spectrum was recorded by direct ${ }^{13} \mathrm{C}$ excitation. For $\mathrm{NaHCO}_{3},{ }^{13} \mathrm{C}$ spectrum was recorded by ${ }^{1} \mathrm{H}-{ }^{13} \mathrm{C}$ CP excitation $\left(\mathrm{t}_{\mathrm{CP}}=4 \mathrm{~ms}\right) . \Delta_{\mathrm{CSA}}$ and $\eta_{\mathrm{CSA}}$ were obtained by fitting the spinning sideband intensities with the DMFIT software. 67

${ }^{43} \mathrm{Ca}$ solid state NMR spectroscopy experiments were carried out on a Bruker Avance III spectrometer operating at a magnetic field of $16.44 \mathrm{~T}$. The corresponding Larmor frequency is 46.8 $\mathrm{MHz}$ for ${ }^{43} \mathrm{Ca}$. Powder samples were packed into $4 \mathrm{~mm}$ zirconia rotors and spun at the magic 
angle at a frequency $v_{\mathrm{MAS}}=14 \mathrm{kHz} \cdot{ }^{43} \mathrm{Ca}$ direct excitation after dual frequency sweep preparation ( ${ }^{43} \mathrm{Ca}$ DFS NMR) spectra were recorded with variable RD indicated in the Figure captions.

${ }^{23} \mathrm{Na}$ solid state NMR spectroscopy experiments were carried out on a Bruker Avance III spectrometer operating at a magnetic field of $7.1 \mathrm{~T}$. The corresponding Larmor frequency is $79.390 \mathrm{MHz}$ for ${ }^{23 \mathrm{Na}}$. Powder samples were packed into $7 \mathrm{~mm}$ zirconia rotors and spun at the magic angle at a frequency $v_{\mathrm{MAS}}=5 \mathrm{kHz}$. Direct acquisition spectra was recorded with a recycle relay $\mathrm{RD}=$ $0.5 \mathrm{~s} .{ }^{1} \mathrm{H}-{ }^{23} \mathrm{Na}$ CP MAS experiments were recorded with $\mathrm{RD}=10 \mathrm{~s}$ and $\mathrm{t}_{\mathrm{CP}}=1 \mathrm{~ms}$. The set-up of the Hartmann-Hahn condition was performed directly on the nacre sample in order to maximize the sensitivity. Low power radio-frequencies irradiation conditions (typically $\nu_{\mathrm{RF}}\left({ }^{1} \mathrm{H}\right)=5 \mathrm{kHz}$ ) were chosen in order to avoid distortion of the quadrupolar ${ }^{23} \mathrm{Na}$ lineshape. $\left\{{ }^{23} \mathrm{Na}\right\}-{ }^{1} \mathrm{H}$ TRAPDOR experiments was recorded with $\mathrm{RD}=10 \mathrm{~s}$ and a recoupling delay $\tau$ of 10 rotor periods i.e. $2 \mathrm{~ms}$.

Chemical shifts were referenced $(0 \mathrm{ppm})$ to TMS $\left({ }^{1} \mathrm{H}\right.$ and $\left.{ }^{13} \mathrm{C}\right)$, saturated aqueous solution of $\mathrm{CaCl}_{2}\left({ }^{43} \mathrm{Ca}\right)$ and $\mathrm{NaCl}\left({ }^{23} \mathrm{Na}\right)$.

\section{DFT calculations}

Geometry optimisations and NMR shielding calculations were carried out by the DFT based CASTEP 8.0 DFT code ${ }^{68,69}$ using the Perdew-Burke-Ernzerhof generalised gradient approximation (PBE-GGA). ${ }^{70}$ The structures were described as extended solids using periodic boundary conditions. In all calculations, the so-called "ultra-soft" pseudopotentials (USPP) 71 were used to describe the interaction of the valence electrons with the nuclei and core electrons.

The all-electron information, needed for the calculation of NMR shielding constants, was reconstructed using the GIPAW 68 method. The wave functions were expanded using a plane wave (PW) basis set with a kinetic energy cut-off of $600 \mathrm{eV}$ that produces converged results for both the geometry optimisation and the calculation of NMR parameters.

The self-consistent field (SCF) calculations were considered to be converged when the total energy of the system was stable within $10^{-5} \mathrm{eV}\left(10^{-7} \mathrm{eV}\right.$ for isolated molecules) for geometry optimization and $10^{-8} \mathrm{eV}$ for NMR calculations. The integrals were calculated over the Brillouin zone with k-point spacing $<0.03 \AA^{-1}$ on the Monkhorst-Pack (MP) mesh. The size of standard grid was set to 2 and size of fine grid to 3 . For the $\mathrm{Na}_{2} \mathrm{CO}_{3}{ }^{72}$ and $\mathrm{NaHCO}_{3}{ }^{73}$ crystals, geometry optimization was 
performed with semi-empirical dispersion correction using the Tkatchenko-Scheffler scheme prior to magnetic resonance calculations. For calculations on isolated molecules, one molecule was placed into a 25x25x25 Angström Supercell to avoid intermolecular interactions.

In order to compare the GIPAW calculated ${ }^{13} \mathrm{C}$ shielding values directly with the experimentally measured isotropic chemical shift values the following expression was used:

$\delta_{\text {iso, calc }}=\sigma_{\text {ref }}-$

$\sigma_{\text {iso }}$

where $\sigma_{\text {ref }}=170.9 \mathrm{ppm}$ is used for ${ }^{13} \mathrm{C}(\mathrm{TMS})^{74,75}$ 


\section{Results and Discussion}

\section{Transmission electron microscopy}

There are only few examples of the description of an amorphous layer in nacre. So far, only two articles reported such observation. ${ }^{46,47}$ The preparation of nacre thin section using a diamond knife can be difficult and tedious due to the exceptional mechanical properties of the material. To overcome this problem, we used focused ion beam (FIB) as an alternative to produce thin cross-section. Then, the surface of the aragonite platelets of $H$. tuberculata's nacre was investigated by HR-TEM. Figure 1a. displays a STEM-HAADF view of the investigated zone where the stacking arrangement of the aragonite tablets is seen. The HR-TEM observation reveals a continuous amorphous layer coating the crystalline lattice of aragonite. This result is in accordance with previous observations performed on H. laevigata ${ }^{46}$ suggesting that the presence of an amorphous layer around aragonite tablets may be more general in abalone nacre than previously assumed. Indeed, if the 3D organisation of aragonite tablets in nacre varies among mollusc taxathe local structure around the tablets within the Haliotidae group seems to be similar. ${ }^{7,76,77}$

We observe that the thickness of such domain is rather homogeneous and is found to be $\sim 5 \mathrm{~nm}$. This amorphous layer appears to be a little bit thicker compared to that observed for H. laevigata: $5 \mathrm{~nm} v s$. 3-5 nm, respectively. Such slight difference in thickness is difficult to discuss since experiments from the literature were performed on older specimen from a different species.

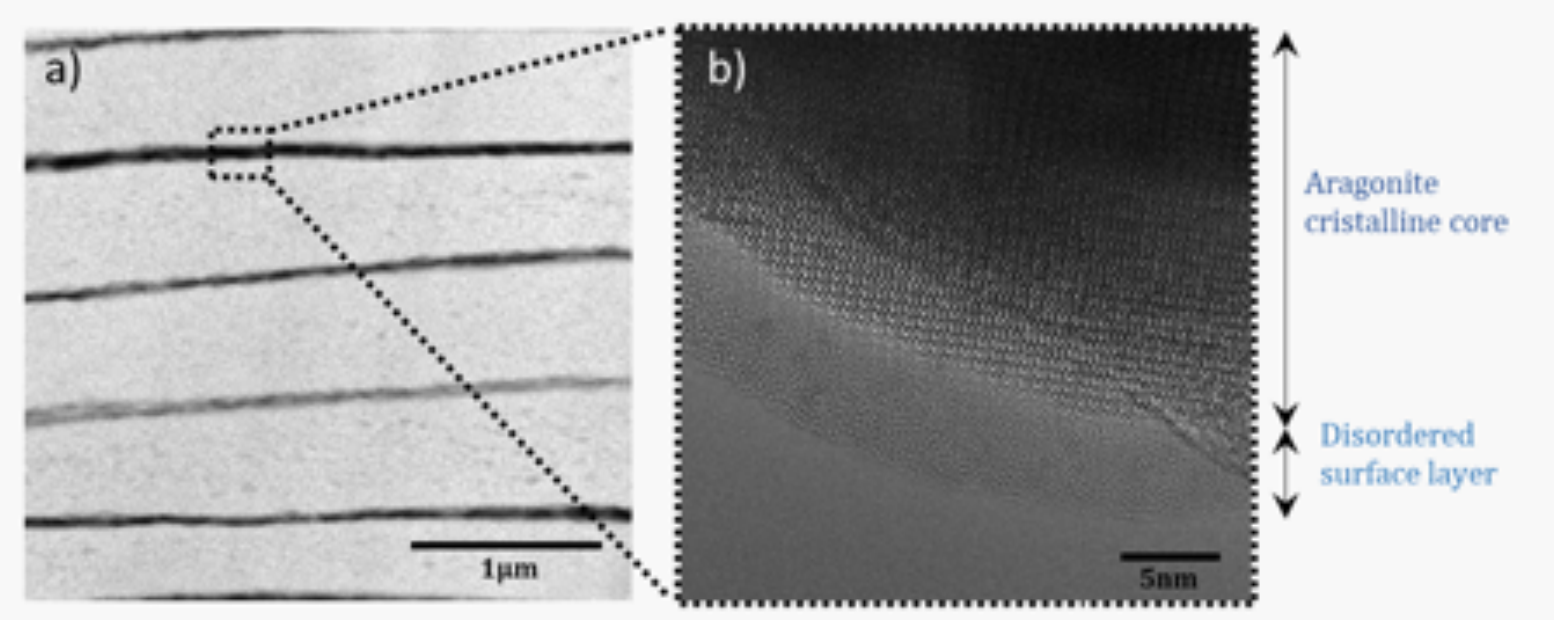


Figure 1: a) STEM-HAADF observations of a thin FIB section of Haliotis tuberculata nacre. b) HRTEM images of the surface of aragonite tablets, revealing the presence of a disordered surface layer.

\section{Solid state NMR study of disordered mineral environments}

\section{Carbonate and bicarbonate ions}

Interestingly, one open question is the nature of this layer described as an ACC-like domain in the literature. To unveil the nature of such disordered mineral domains, we used ssNMR to clear its ionic composition. As mentioned above, solid state NMR is a particularly suitable spectroscopy for the study of calcified biological tissues thanks to its non-destructive aspect and enables the study of organic and mineral species independently or in a correlated manner in order to probe their interfaces. ${ }^{78,79}$ Moreover, it was shown that ssNMR allows the specific edition of surface (vs. bulk) biomineral species and provides access to structural and dynamical information at the atomic scale for the surface layer of different biominerals. ${ }^{49,58}$

Since nacre is composed of carbon-containing species in both the organic and the mineral fractions, the choice of specific NMR pulse sequences is mandatory to edit the different components of nacre and distinguish aragonite from the surrounding organic matrix. Significantly, Figure 2 displays the direct ${ }^{13} \mathrm{C}$ and ${ }^{1} \mathrm{H}-{ }^{13} \mathrm{C}$ CP MAS NMR spectra of $H$. tuberculata's nacre. As the ${ }^{13} \mathrm{C}$ chemical shift allows the identification of the different $\mathrm{CaCO}_{3}$ crystalline polymorphs (calcite, aragonite and vaterite), ${ }^{80}$ the direct ${ }^{13} \mathrm{C}$ acquisition NMR spectrum (Fig. 2a) highlights that the mineral part is composed of highly ordered aragonite crystals as shown by the single thin characteristic resonance at $\delta\left({ }^{13} \mathrm{C}\right)=171 \mathrm{ppm}(\mathrm{LW}=0.6 \mathrm{ppm})$. In addition, the organic fraction is hardly observed in this spectrum because of its small proportion (less than $5 \mathrm{w} \%$ ).

In contrast, ${ }^{1} \mathrm{H}$ to ${ }^{13} \mathrm{C}$ cross polarization experiments reveals carbon species in proton-rich environment such as found in the organic matrix. Consequently, the ${ }^{1} \mathrm{H}-{ }^{13} \mathrm{C}$ CP MAS NMR spectrum, recorded with $\mathrm{RD}=1 \mathrm{~s}$ and $\mathrm{t}_{\mathrm{CP}}=1 \mathrm{~ms}$, reveals the main organic components of $H$. tuberculata's nacre and in particular, $\beta$-chitin as the corresponding ${ }^{13} \mathrm{C}$ resonances seem to be present between 50 and $110 \mathrm{ppm}^{23}$ (Fig. 2c). Moreover, additional resonances in the range 20-50 ppm together with the strong carbonyl resonance at $175 \mathrm{pp}$ might correspond to proteinaceous material. ${ }^{81}$ 
Finally, the so-called "interfacial" mineral species, which are nearby a proton source, are also accessible through ${ }^{1} \mathrm{H}-{ }^{13} \mathrm{C}$ CP MAS NMR experiment. It was shown in the literature that they can be revealed by changing the CP MAS NMR conditions compared to those used to edit the organic components..$^{46,57}$ Indeed, longitudinal relaxation time parameters $\left(T_{1}\left({ }^{1} \mathrm{H}\right)\right.$ and $\left.T_{1} \rho\left({ }^{1} \mathrm{H}\right)\right)$ are much longer for interfacial mineral species. Thus, by using longer recycle delay $(\mathrm{RD}=10 \mathrm{~s})$ and longer contact time $\left(\mathrm{t}_{\mathrm{CP}}=10 \mathrm{~ms}\right)$, the organic resonances are no longer observed (due to $T_{1} \rho\left({ }^{1} \mathrm{H}\right)$ relaxation) and a single resonance centered on a similar chemical shift of aragonite is revealed (Fig. 2b). This signal, significantly broader and asymmetric (shoulder on the right), corresponds to interfacial carbonates of H. tuberculata's nacre nearby a ${ }^{1} \mathrm{H}$-rich environment. Such observation is in accordance with similar experiments performed on the nacre from $H$. laevigata for which the resulting ${ }^{13} \mathrm{C}$ signal were assigned to carbonates within the ACC-like surface layer of aragonite tablets. ${ }^{46}$

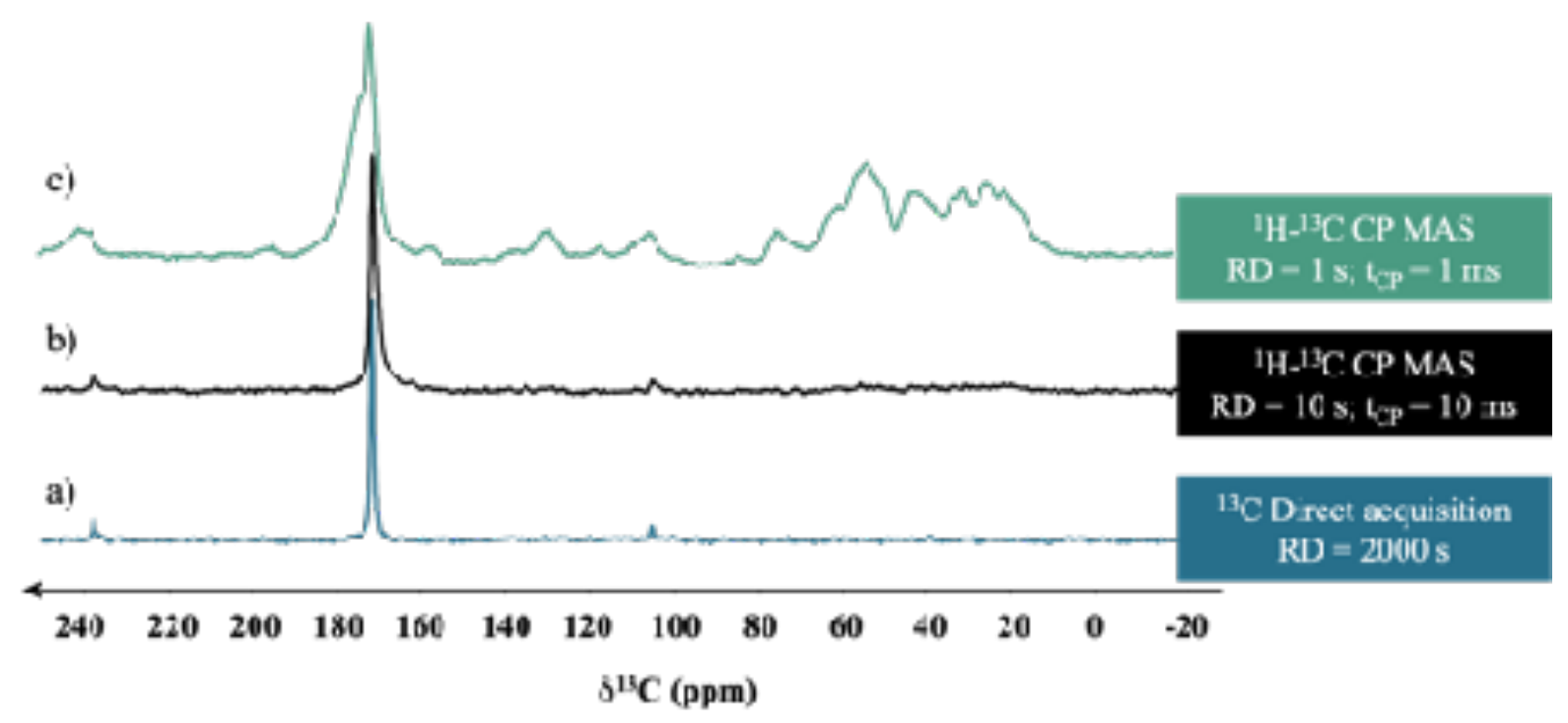

Figure 2. ${ }^{13} \mathrm{C}$ NMR spectra of Haliotis tuberculata's nacre: a) direct acquisition $\left.(R D=2000 \mathrm{~s}), \mathrm{b}\right) \mathrm{CP}$ $\left.\operatorname{MAS}\left(R D=10 \mathrm{~s} ; t_{C P}=10 \mathrm{~ms}\right), c\right) C P M A S\left(R D=1 \mathrm{~s} ; t_{C P}=1 \mathrm{~ms}\right)$.

Decreasing the contact time would be of great interest to characterize more precisely such disordered carbonates. However, at shorter contact time ( $\left.\mathrm{t}_{\mathrm{CP}}<10 \mathrm{~ms}\right)$, the strong overlap with the $\mathrm{C}=\mathrm{O}$ signal from the organic phase prevents such study (Fig. S1). To avoid the presence of such unwanted ${ }^{13} \mathrm{C}$ organic signals, we have taken advantage of the difference in transverse relaxation time $\left(T_{2}\left({ }^{1} \mathrm{H}\right)\right)$ between the organic and the disordered mineral domains, particularly at moderate static magnetic field 
and MAS frequency $\left(\mathrm{B}_{0}=7 \mathrm{~T}\right.$ and $v_{\mathrm{MAS}}=5 \mathrm{kHz}$, respectively, in the present study). Indeed, the proton homonuclear dipolar coupling is higher for the organic phase due to a higher density of proton leading to shorter $T_{2}\left({ }^{1} \mathrm{H}\right)$ compared to the disordered mineral phase (Fig. S2). Consequently, addition of a ${ }^{1} \mathrm{H}-$ echo sequence $(\pi / 2-\tau-\tau-\tau)$, before the cross polarization sequence, acts as a $T_{2}\left({ }^{1} \mathrm{H}\right)$-filter and enables the removal of organic ${ }^{13} \mathrm{C}$ signals at $\mathrm{t}_{\mathrm{CP}}$ shorter than $10 \mathrm{~ms}\left({ }^{1} \mathrm{H}\right.$-echo- ${ }^{13} \mathrm{C}$ CP MAS experiment; Fig. S1). A similar approach was recently used through the implementation of ${ }^{1} \mathrm{H}$ double filtering techniques $\left(T_{1}\right.$ and $\left.T_{2}\right)$ that were successfully used to reveal hidden proton resonances in biomimetic mineral composites. ${ }^{82}$ The resulting ${ }^{1} \mathrm{H}-$ echo- ${ }^{13} \mathrm{C}$ CP MAS NMR experiment at short contact time ( $\mathrm{t}_{\mathrm{CP}}$ $=4 \mathrm{~ms}$ ) displays a spectrum (Fig. 3) more complex to what is observed in standard CP conditions (Fig. S3) and to what is usually shown in the literature. $46,57,58$ In the conditions set here, at least three different carbonate resonances are revealed (see Table 1): one sharp resonance at $\delta\left({ }^{13} \mathrm{C}\right)=171$ (resonance A), a twice larger resonance at $\delta\left({ }^{13} \mathrm{C}\right)=170 \mathrm{ppm}$ (resonance $\left.\mathrm{B}\right)$ and a broad one ranging from 161 to $168 \mathrm{ppm}$ with a maximum at $166 \mathrm{ppm}$ (resonance C) that was barely observable at long $t_{C P}=10 \mathrm{~ms}$ (Fig; 1). Interestingly, this experiment highlights that the disordered mineral domain in nacre of $H$. tuberculata is structurally more complex than an ACC phase as previously proposed for $H$. laevigata. ${ }^{46}$ The resonance A possesses a chemical shift and linewidth very close to biogenic crystalline aragonite and might arise from carbonate still in the crystalline lattice but close from a source of proton. Resonance B is slightly shifted to lower value and displays a linewidth two-times broader and might correspond to $\mathrm{CO}_{3}^{2-}$ still in an aragonitic environment but of disordered neighborhood. Concerning resonance $\mathrm{C}$, the assignment of is less straightforward. According to its chemical shift, resonance $\mathrm{C}$ might correspond to several environments: $\mathrm{CO}_{3}{ }^{2-}$ in calcitic or in ACClike environment (around $168.5 \mathrm{ppm})^{79}$ or $\mathrm{HCO}_{3}^{-}$in bicarbonate salt-like environment such as $\mathrm{NaHCO}_{3}(167 \mathrm{ppm}-$ see Table S1). 


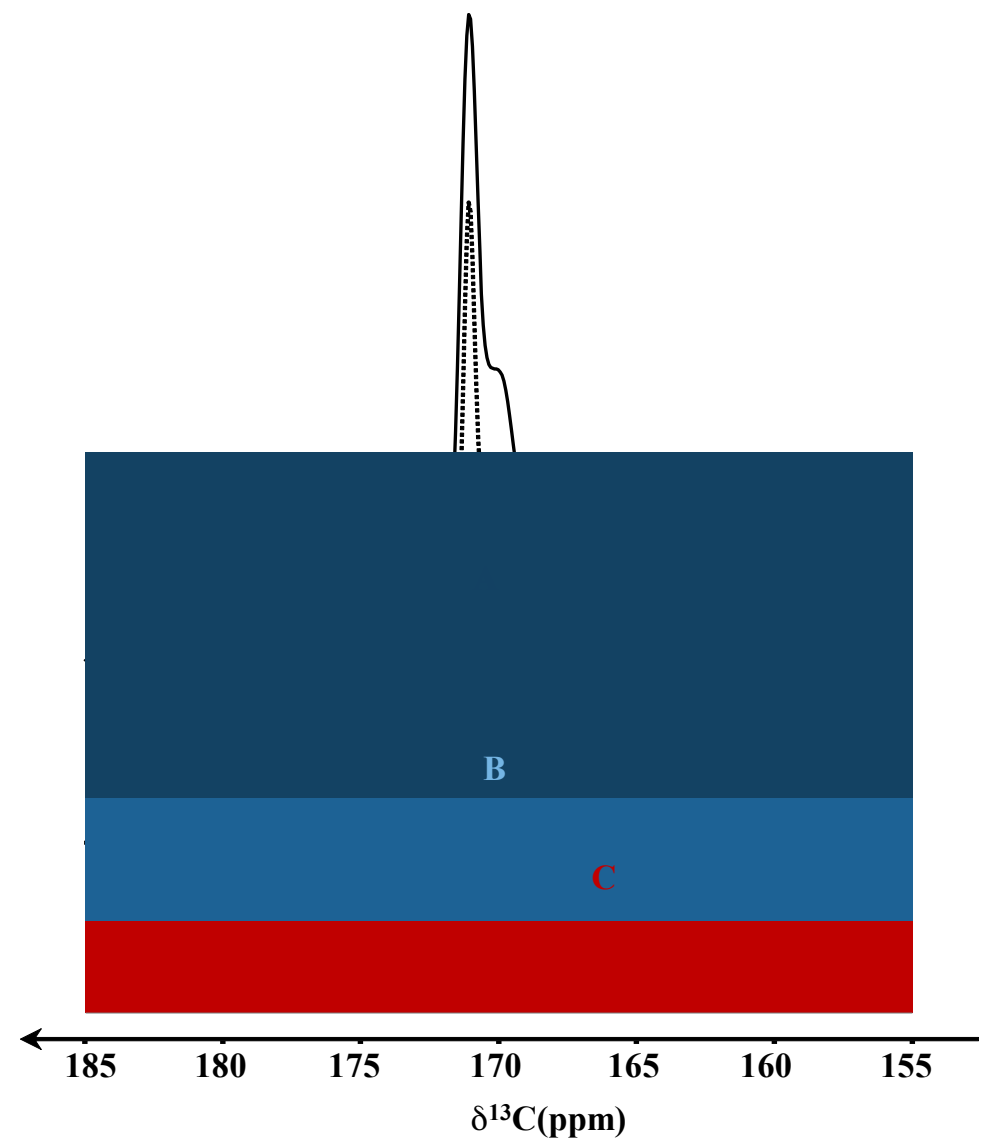

Figure 3: ${ }^{1} \mathrm{H}$-echo-13C CP MAS NMR spectrum of Haliotis tuberculata's nacre ( $R D=10 \mathrm{~s} ; t_{C P}=4 \mathrm{~ms}$; $\tau=0.2 \mathrm{~ms})$ together with its spectral deconvolution highlighting three main resonances.

\begin{tabular}{|c|c|c|c|}
\hline & Resonance A & Resonance B & Resonance C \\
\hline${ }^{13}$ C Chemical shift $(\mathrm{ppm})$ & 171 & 170 & 166 \\
\hline Linewidth $(\mathrm{ppm})$ & 0.7 & 1.6 & 5.4 \\
\hline$\Delta_{\mathrm{CSA}}(\mathrm{ppm})$ & $-53 \pm 5$ & $-55 \pm 5$ & $+43 \pm 15$ \\
\hline$\eta_{\mathrm{CSA}}$ & $0.3 \pm 0.1$ & $0.5 \pm 0.1$ & $0.8 \pm 0.2$ \\
\hline$T_{\mathrm{CH}}(\mathrm{ms})$ & $5.00 \pm 0.50$ & $1.90 \pm 0.10$ & $0.90 \pm 0.02$ \\
\hline Assignment & $\mathrm{CO}_{3}{ }^{2-}$ & $\mathrm{CO}_{3}{ }^{-}$ & $\mathrm{HCO}_{3}$ \\
\hline
\end{tabular}

Table 1: ${ }^{13} C$ NMR parameters of the resonance $A, B$ and $C$ evidenced in Fig. 3 and their relative assignement. The ${ }^{13} C$ CSA tensorial parameters $\Delta_{\text {CSA }}$ and $\eta_{\text {CSA }}$ are defined as follow: $\Delta_{C S A}=\delta_{33}-\delta_{i s o}$ and $\eta_{C S A}=\left(\delta_{22}-\delta_{11}\right) /\left(\delta_{33}-\delta_{i s o}\right)$ with $\delta_{i s o}=1 / 3\left(\delta_{11}+\delta_{22}+\delta_{33}\right)$ and the chemical shielding principal values $\delta_{11}, \delta_{22}, \delta_{33}$ ordered as follows: $\left|\delta_{33}-\delta_{\text {iso }}\right| \geq\left|\delta_{11}-\delta_{\text {iso }}\right| \geq\left|\delta_{22}-\delta_{i s o}\right|$. The cross polarization parameters $M_{0}$ and $T_{C H}$ are obtained through Eq. 1. 
In addition to the isotropic ${ }^{13} \mathrm{C}$ chemical shift, the chemical shift anisotropy (CSA) also informs on the chemical environment. The CSA depends on the electronic distribution around the nucleus and is thus very sensitive to the symmetry of the carbon sites. As a consequence, the origin of the CSA is essentially intramolecular for small rigid molecules with hybridized ${ }^{13} \mathrm{C}$ atomic orbitals. Hence for carbonate ions, the protonation state $\left(\mathrm{CO}_{3}{ }^{2-} v s . \mathrm{HCO}_{3}^{-}\right)$can be determined on the basis of the CSA parameters $\left(\Delta_{\mathrm{CSA}}\right.$ and $\left.\eta_{\mathrm{CSA}}\right)$. For this purpose, we compared theoretical DFT calculations both for free ions $\left(\mathrm{CO}_{3}^{2-} v s . \mathrm{HCO}_{3}^{-}\right)$and crystalline systems $\left(\mathrm{Na}_{2} \mathrm{CO}_{3}\right.$ vs. $\left.\mathrm{NaHCO}_{3}\right)$ and found very different CSA values being, to some extent, modulated by the crystalline environments (Table S1 and Fig. S4). Strikingly, $\Delta_{\mathrm{CSA}}$ theoretical values are found to be either positive or negative according to the protonation state: negative values for $\mathrm{CO}_{3}^{2-}\left(-46.8 \mathrm{ppm}\right.$ for the DFT calculations in $\mathrm{Na}_{2} \mathrm{CO}_{3}$ crystal) and positive values for $\mathrm{HCO}_{3}^{-}\left(+63.6 \mathrm{ppm}\right.$ for DFT calculations in $\mathrm{NaHCO}_{3}$ crystal). We also experimentally determined the CSA parameters for the two crystalline reference samples $\mathrm{Na}_{2} \mathrm{CO}_{3}$ and $\mathrm{NaHCO}_{3}$ (by fitting of the spinning side bands manifold of ${ }^{13} \mathrm{C}$ spectra). It appears that the experimental values for the crystalline reference samples are in good agreement with the theoretical values and possess characteristic negative $(\approx-51 \mathrm{ppm})$ and positive $(\approx+62 \mathrm{ppm}) \Delta_{\text {CSA }}$ values for $\mathrm{Na}_{2} \mathrm{CO}_{3}$ and $\mathrm{NaHCO}_{3}$ respectively (Fig. S4 and Table $\mathrm{S} 1$ ). The calculations on pure ideal ions allow to understand the switch of the sign of CSA asymmetry parameter based on symmetry consideration. Similar results have been observed for CSA asymmetry parameter of phosphate ions for which the sign of $\Delta_{\mathrm{CSA}}$ depends on the protonation state. 83 Therefore, the determination of ${ }^{13} \mathrm{C} \mathrm{CSA}$ can inform on the nature of the various carbonate ions in nacre's disordered mineral domain.

Thus, we performed ${ }^{1} \mathrm{H}-{ }^{13} \mathrm{C}$ CP MAS experiment at slow MAS frequency $\left(v_{\mathrm{MAS}}=1.5 \mathrm{kHz}\right)$ on H. tuberculata's nacre to acquire the ${ }^{13} \mathrm{C}$ CSA spinning side bands manifold and to extract the ${ }^{13} \mathrm{C} \mathrm{CSA}$ parameters $\left(\Delta_{\mathrm{CSA}}\right.$ and $\left.\eta_{\mathrm{CSA}}\right)$ for the three resonances, namely $\mathrm{A}, \mathrm{B}$ and $\mathrm{C}$. The corresponding spectrum is depicted in Figure 4 together with the corresponding fitting (CSA parameters are listed in Table 1). Resonance $\mathrm{A}$ and $\mathrm{B}$ display close negative $\Delta_{\mathrm{CSA}}$ values (-53 and $-55 \pm 5 \mathrm{ppm}$, respectively), whereas resonance $\mathrm{C}$ possesses a positive $\Delta_{\mathrm{CSA}}$ value $(+43 \pm 5 \mathrm{ppm})$. According to our CSA parameters DFT calculations, resonances $\mathrm{A}$ and $\mathrm{B}$ can be safely assigned to $\mathrm{CO}_{3}{ }^{2-}$ and the resonance $\mathrm{C}$ to $\mathrm{HCO}_{3}^{-}$. It is worth noticing that our experimentally determined CSA parameters are in accordance with previous data reported in the literature for various calcium carbonates phases, ${ }^{84,85}$ and in particular, for 
aragonite for which the $\Delta_{\mathrm{CSA}}$ and $\eta_{\mathrm{CSA}}$ are very close (-53.5 ppm and 0.2 , respectively), confirming the aragonitic environment around resonance $\mathrm{A}$ and $\mathrm{B}$. Concerning, resonance $\mathrm{C}$, we observe a $\Delta_{\mathrm{CSA}}$ much lower than the reference compound ( $+43 \mathrm{vs}+62 \mathrm{ppm}$ for $\left.\mathrm{NaHCO}_{3}\right)$ that can be explained by the relatively poor $\mathrm{S} / \mathrm{N}$ and the difficulty to determine precise experimental $\Delta_{\text {CSA }}$ value for resonance $\mathrm{C}$. Finally, we note that such approach consisting in the careful examination of the spinning side band manifold of slow MAS ${ }^{13} \mathrm{C}$ NMR spectra for carbonate/bicarbonate differentiation has already been used to evidence the partition of carbon dioxide into $\mathrm{CO}_{3}^{2-}$ or $\mathrm{HCO}_{3}$ - inside layered double hydroxide materials. ${ }^{86}$ Our results confirm that the disordered mineral domain in nacre is different from a biogenic ACC for which one homogeneous single broad resonance is observed. ${ }^{87}$ By contrast here, different carbonate resonances are observed reflecting different chemical environments and different protonation state indicating relatively well structured $\mathrm{CO}_{3}{ }^{2-}$ and more structurally disordered $\mathrm{HCO}_{3}{ }^{-}$ possessing a distribution of ${ }^{13} \mathrm{C}$ chemical shifts.

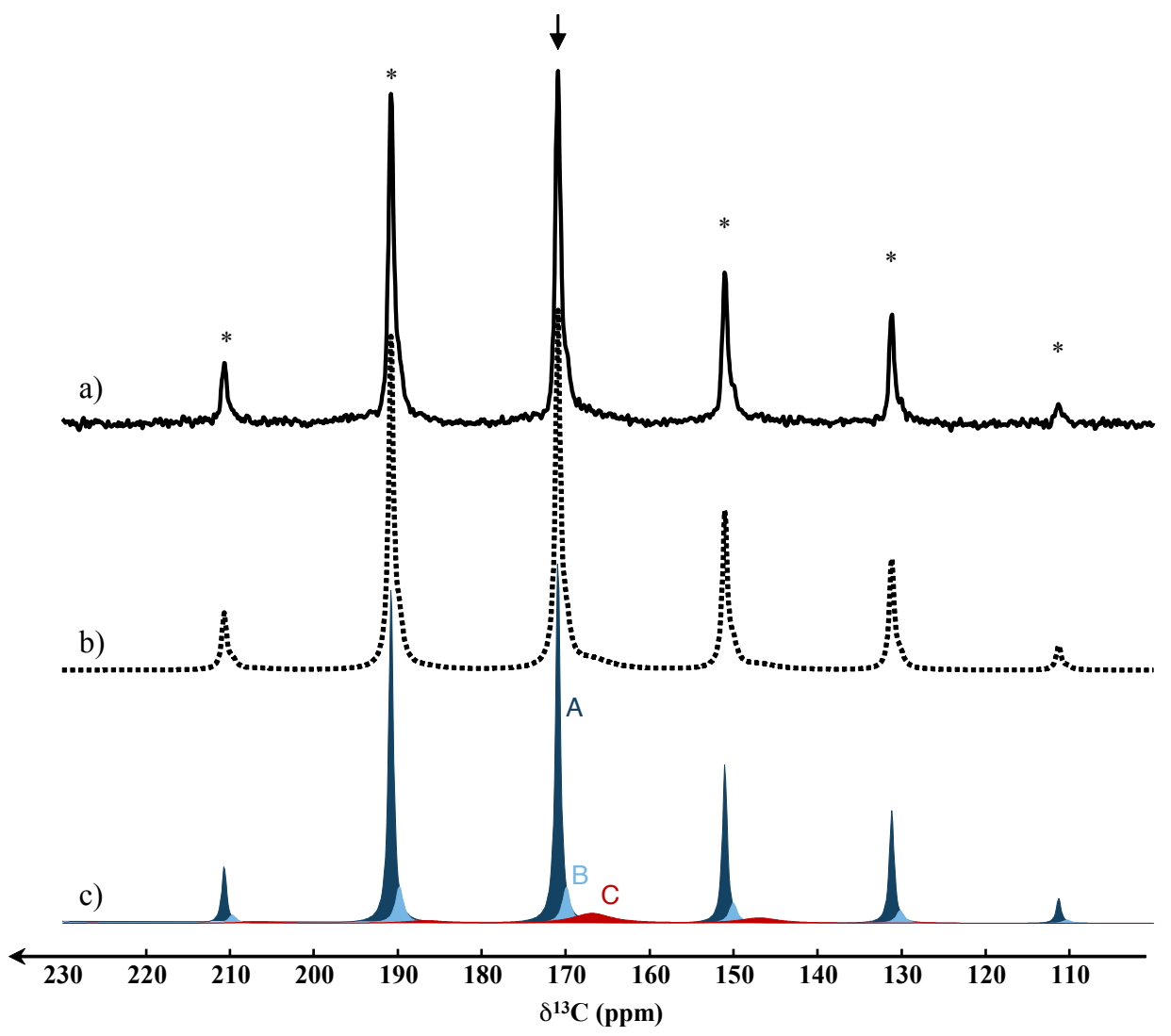


Figure 4. a) ${ }^{1} \mathrm{H}-{ }^{13} \mathrm{C} C P \mathrm{MAS} N \mathrm{NR}$ spectrum $\left(R D=10 \mathrm{~s}, t_{C P}=10 \mathrm{~ms} ; v_{M A S}=1.5 \mathrm{kHz}\right)$ of Haliotis tuberculata's nacre and b) the corresponding fitting: c) dark blue: resonance A; light blue: resonance B; red: resonance C. arrow: isotropic resonance; stars: spinning side bands.

To go further, in order to identify the source of proton magnetization in the CP experiment, we performed two dimensional ${ }^{1} \mathrm{H}$-echo- ${ }^{13} \mathrm{C}$ HetCor NMR experiment at short contact time ( $\left.\mathrm{t}_{\mathrm{CP}}=4 \mathrm{~ms}\right)$ as shown in Figure 5. Two main ${ }^{1} \mathrm{H}$ resonances are observed at 5 and $14.5 \mathrm{ppm}$ allowing the identification of the source of proton magnetization in disorder domains. The two resonances are assigned to $\mathrm{H}_{2} \mathrm{O}$ and proton from $\mathrm{HCO}_{3}^{-}$, respectively, based on their chemical shift. The latter assignment is made on the basis of $2 \mathrm{D}{ }^{1} \mathrm{H}_{-13}{ }^{13} \mathrm{C}$ HETCOR spectrum of crystalline $\mathrm{NaHCO}_{3}$ (Fig. S5). This ${ }^{1} \mathrm{H}$ resonance confirms the presence of bicarbonate ions in the disordered domain. More specifically, both carbonates and bicarbonate $\mathrm{A}, \mathrm{B}$ and $\mathrm{C}$ correlate with protons in $\underline{\mathrm{HCO}_{3}}{ }^{-}$and $\underline{\mathbf{H}} 2 \mathrm{O}$ (Fig. 5). This result demonstrates the proximity between $\mathrm{CO}_{3}^{2-}(\mathrm{A}$ and $\mathrm{B})$ and $\mathrm{HCO}_{3}^{-}(\mathrm{C})$ with both protons from bicarbonates and, to a lesser extent, from rigid $\mathrm{H}_{2} \mathrm{O}$ molecules and suggests that these species are located in the same disordered domain. The careful examination of the correlation resonance involving bicarbonate $\mathrm{C}$ reveals a distribution of chemical shift both for ${ }^{13} \mathrm{C}$ (from 164 to $169 \mathrm{ppm})$ and ${ }^{1} \mathrm{H}$ resonances (from 13 to $15 \mathrm{ppm}$ ) where $\delta\left({ }^{1} \mathrm{H}\right)$ decreases together with $\delta\left({ }^{13} \mathrm{C}\right)$.

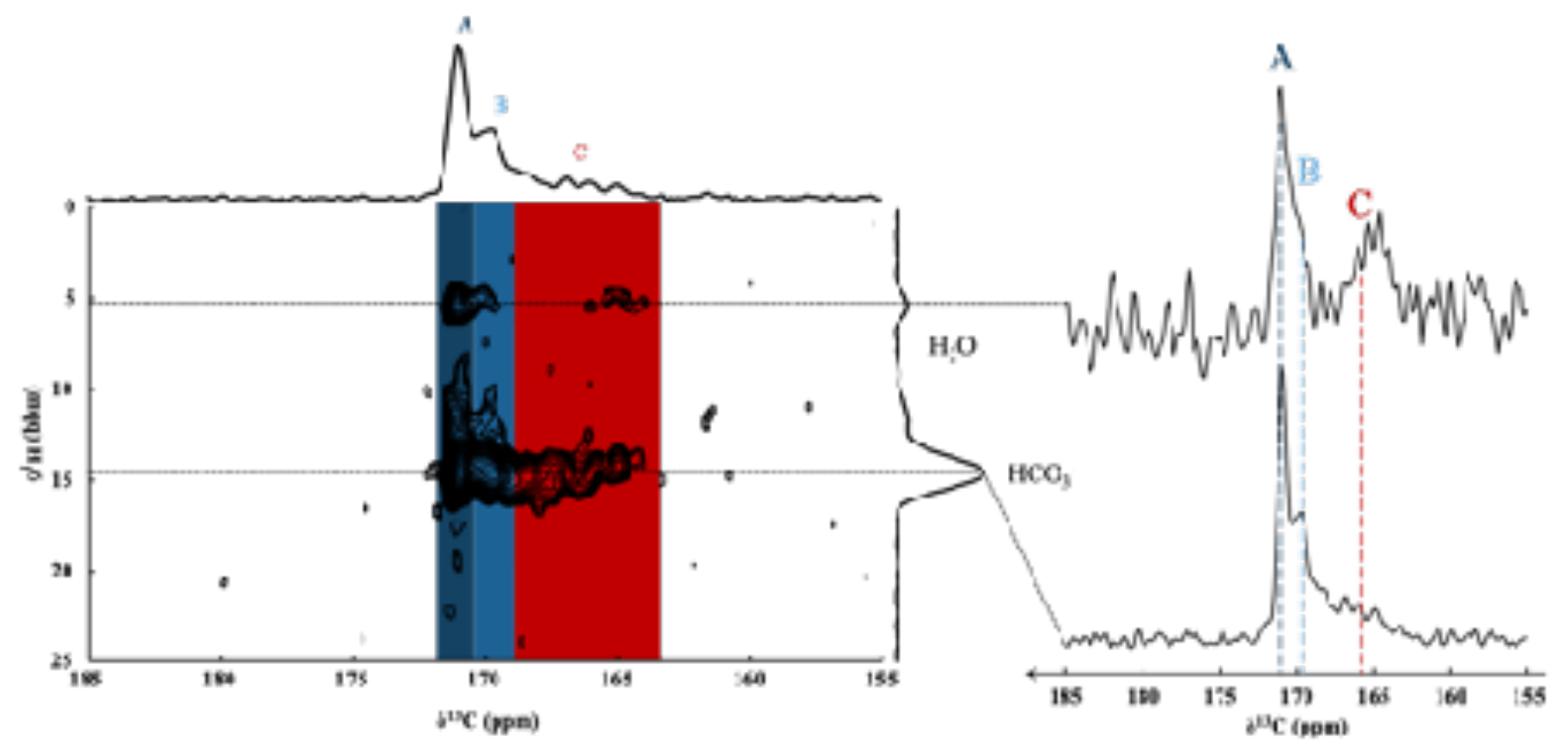

Figure 5. $2 D^{1} \mathrm{H}$-echo- ${ }^{13} \mathrm{C}$ HetCor NMR spectrum $\left(R D=10 \mathrm{~s} ; t_{C P}=4 \mathrm{~ms} ; \tau=0.2 \mathrm{~ms}\right)$ of Haliotis tuberculata's nacre together with comparison of the ${ }^{13} \mathrm{C}$ rows extracted at $\delta\left({ }^{1} \mathrm{H}\right)=5$ and $15 \mathrm{ppm} .$. 
To go further in the study of the disordered environment, we performed an analysis of the $\mathrm{CP}$ dynamic through the variation of the contact time $t_{C P}$. The ${ }^{13} \mathrm{C}$ magnetization evolution is a direct indication of the ${ }^{1} \mathrm{H}-{ }^{13} \mathrm{C}$ dipolar coupling strength that depends on the ${ }^{1} \mathrm{H}-{ }^{13} \mathrm{C}$ spatial proximity between the two nuclei and thus informs on proton environment around carbonate ions.

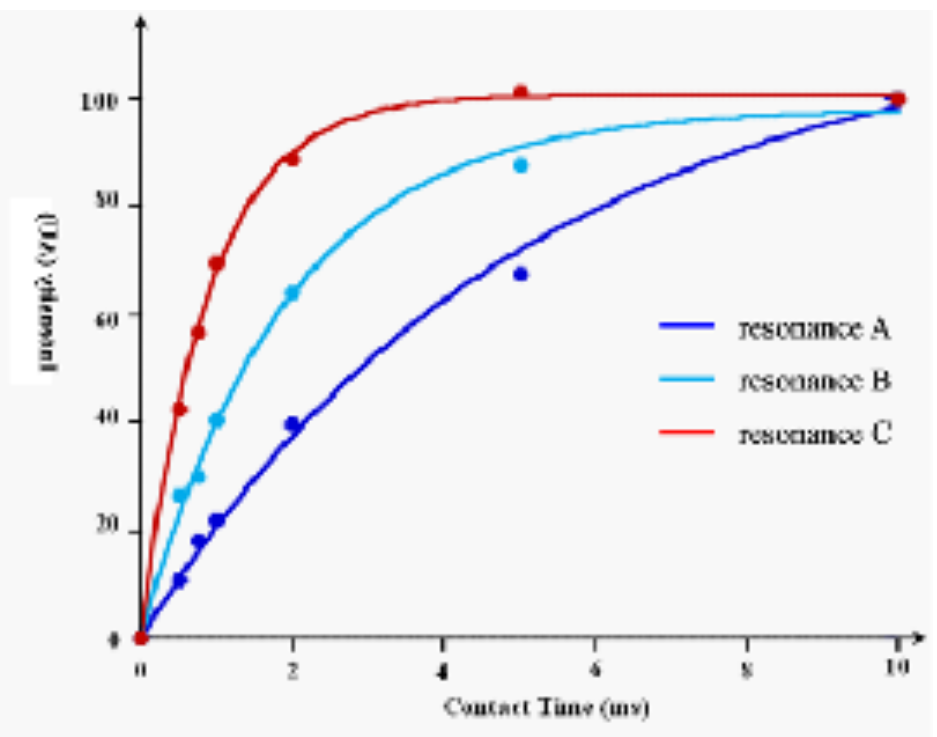

Figure 6: Evolution of the normalized ${ }^{13} \mathrm{C}$ magnetization recorded through variable contact time ${ }^{1} \mathrm{H}-$ echo-13C CP MAS NMR experiments for Haliotis tuberculata's nacre $(R D=10 \mathrm{~s} ; \tau=0.2 \mathrm{~ms})$. Dark

blue: resonance A; light blue: resonance B; red: resonance C. Solid lines are the numerical simulations according to Eq. 1.

Figure 6 shows the evolution of the normalized ${ }^{13} \mathrm{C}$ magnetization for the three resonances of interest and the corresponding numerical simulation carried out through the classical I-S model:

$$
\mathrm{M}(\mathrm{t})=\mathrm{M}_{0} \times\left(1-\exp \left(-\mathrm{t}_{\mathrm{CP}} / T_{\mathrm{CH}}\right)\right)
$$

where $\mathrm{M}_{0}, \mathrm{t}_{\mathrm{CP}}, T_{\mathrm{CH}}$, are the $\mathrm{CP}$ intensity, the contact time, the $\mathrm{CP}$ rate constant, respectively. Table 1 gathers the numerically extracted CP dynamic parameters. Different CP MAS behaviors emerge: resonance $\mathrm{C}$ exhibits a rapid growth of the ${ }^{13} \mathrm{C}$ magnetization (short $T_{\mathrm{CH}}$ ) characteristic of bicarbonate for which the main source of proton is intramolecular. On the other hand, carbonate A possesses the slowest magnetization growth meaning the furthest proton source (water molecule and proton from 
bicarbonate according to the $2 \mathrm{D}$ HetCor). Interestingly, carbonate B possesses intermediate $T_{\mathrm{CH}}$ value revealing that carbonate $\mathrm{B}$ is closer to the proton source (still water molecule and proton from bicarbonate according to the 2D HetCor) than carbonate A.

As a conclusion, the ${ }^{13} \mathrm{C}$ ssNMR study reveals that disordered mineral domains in nacre of $H$. tuberculata is composed of bicarbonates and at least two types of ${ }^{1} \mathrm{H}$-polarizable carbonates. These carbonates are distinguished on the basis of their relative proximity with respect to the proton source. As a consequence, in the case of interfacial disordered mineral domains, our results suggest the presence: (i) slightly disordered carbonate in an aragonitic environment; (ii) more distorted aragonitic carbonates close to structural water and bicarbonates; and finally, (iii) highly disordered bicarbonates.

If some ssNMR structural studies of carbonates ions and their interface in carbonatebased biomineralized systems exist in the literature $46,57,87,88,89$ according to our knowledge, an equivalent study of the cations as counter-ions is missing.

\section{Counter ion study: $\mathrm{Ca}^{2+}$}

There are only few examples of biogenic calcium carbonate study through ${ }^{43} \mathrm{Ca}$ solid state NMR. To the best of our knowledge, only one paper reports ${ }^{43} \mathrm{Ca}$ NMR spectra of crystalline aragonite in coral and in mussel pearl. ${ }^{90}$, Such a study is essential to investigate the local environment around $\mathrm{Ca}^{2+}$ within both the crystalline lattice and the disordered environments of the nacre tablets. The ${ }^{43} \mathrm{Ca}$ nucleus is of very low sensitivity due to its low natural abundance $(0.14 \%)$, its low gyromagnetic ratio (7\% compared to $\gamma\left({ }^{1} \mathrm{H}\right)$ ) and its spin $7 / 2$. Thus, natural abundance experiments usually require large sample volumes, high magnetic field and signal-enhancing NMR pulse sequences such as dual frequency sweep (DFS) ${ }^{91}$.

Figure 7a displays the ${ }^{43} \mathrm{Ca}$ DFS NMR spectra of $H$. tuberculata's nacre recorded at $16.44 \mathrm{~T}$. A single thin resonance at $\delta\left({ }^{43} \mathrm{Ca}\right)=-30 \mathrm{ppm}$ is observed in agreement with a synthetic aragonite reference sample (Fig. 7e). However, we note that the linewidth is larger in the case of nacre revealing a higher local disorder in the crystalline lattice of the biogenic sample. It was shown that $T_{1}\left({ }^{43} \mathrm{Ca}\right)$ in synthetic highly crystalline aragonite is unusually long for a quadrupolar nucleus. ${ }^{92}$ Thus, reducing the 
recycle delay from 30 to $1 \mathrm{~s}$ (Fig. 7a-c) acts as a $T_{1}$ filter. As a result, it leads to the decrease of the relative intensity of the ${ }^{43} \mathrm{Ca}$ crystalline aragonite resonance and reveals the presence of a deshielded signal as a left broad shoulder $(\delta=-26 \mathrm{ppm}, \mathrm{LW}=20 \mathrm{ppm})$. The gaussian lineshape of this signal suggests a distribution of disordered environments (Fig. 7d). This is confirmed by the comparison with the ${ }^{43} \mathrm{Ca}$ DFS NMR spectrum of an ACC reference sample that displays analogous position and linewidth (Fig. 7f). To the best of our knowledge, this is the first time that highly disordered $\mathrm{Ca}^{2+}$ environments are evidenced in nacre. This result strongly suggests that $\mathrm{Ca}^{2+}$ ions localize within the disordered mineral domain as counter-ions of the carbonates evidenced previously.

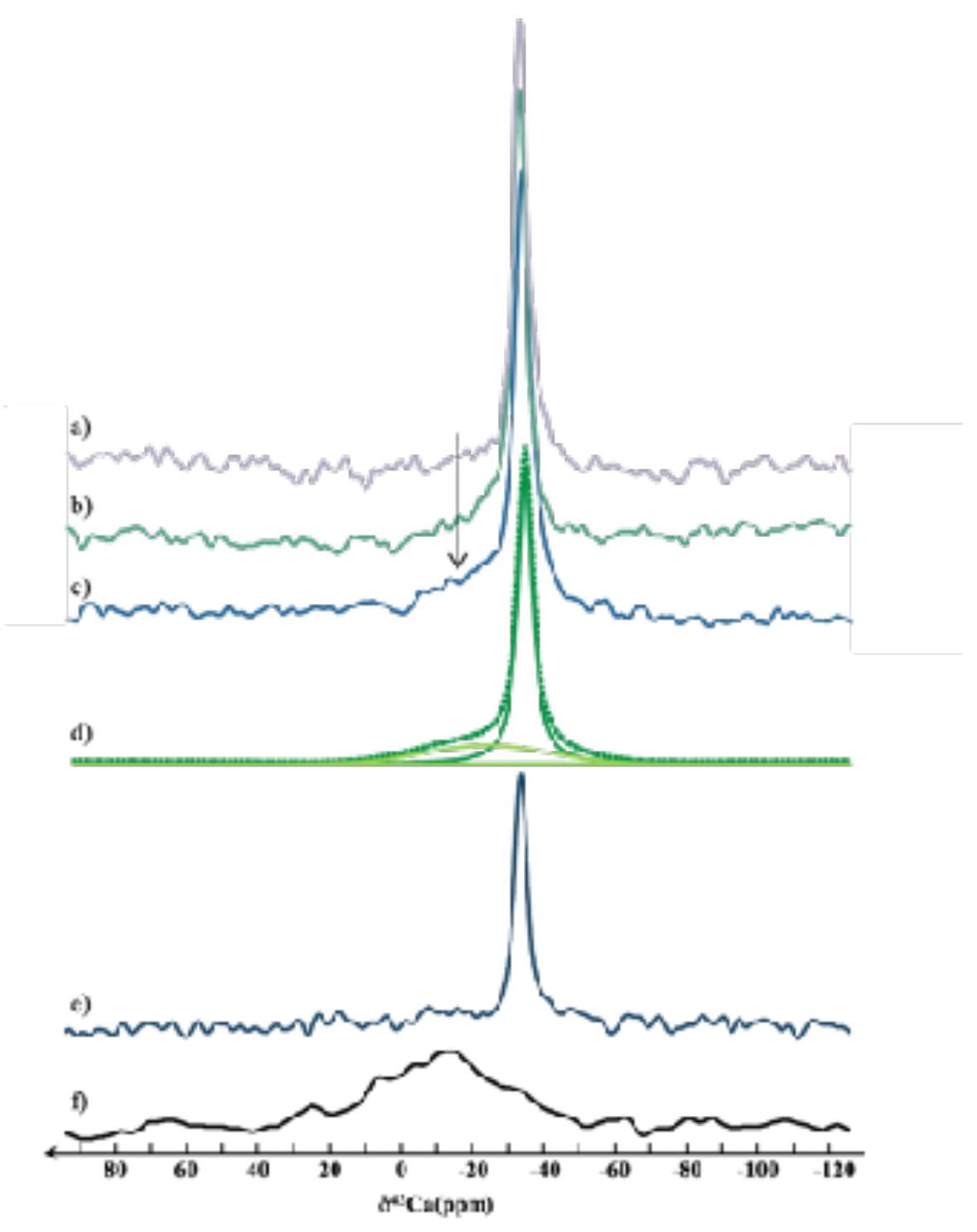


Figure 7: ${ }^{43}$ Ca DFS NMR spectra of Haliotis tuberculata's nacre recorded with the following recycle delays: a) $R D=30 s, b) R D=5 s, c) R D=1$ s. d) fitting of the spectrum c). ${ }^{43} C a$ DFS NMR spectra of e) synthetic aragonite and f) ACC. The arrow highlights calcium in disordered environments.

\section{Counter ion study: $\mathrm{Na}^{+}$}

The presence of monovalent anions $\left(\mathrm{HCO}_{3}-\right)$ in such disordered mineral domain also questions the presence of monovalent cations as counter-ions in addition to $\mathrm{Ca}^{2+}$. We focused on sodium ions, the most abundant cation in seawater $\left(10.7\right.$ g.L-1), as $\mathrm{Na}^{+}$has been shown to be the most abundant minor element in biogenic $\mathrm{CaCO}_{3}$ from corals, bivalves, and foraminifera. ${ }^{93}$ For instance, the amount of $\mathrm{Na}^{+}$ranges from $\sim 2000$ to $\sim 4000 \mathrm{ppm}$ in marine Molluscs shell. However, to the best of our knowledge, investigation by ${ }^{23} \mathrm{Na}$ ssNMR of $\mathrm{Na}^{+}$in nacre is performed for the first time. Direct ${ }^{23 \mathrm{Na}}$ acquisition NMR spectrum (Fig. S6) displays three resonances centered at 0, -16 and -22 ppm. The 0 ppm resonance corresponds to residual $\mathrm{NaCl}$ (Fig. S6), certainly originating from seawater, whereas the third peak at $-22 \mathrm{ppm}$ is still from unknown origin. The $1 \mathrm{D}{ }^{1} \mathrm{H}-{ }^{23} \mathrm{Na}$ CP MAS NMR spectrum displays only one broad single resonance centered at $-16 \mathrm{ppm}$ without any quadrupolar lineshape suggesting the presence of sodium ions in disordered environments. The two dimensional ${ }^{1} \mathrm{H}-{ }^{23} \mathrm{Na}$ Hetcor experiment (Fig. 8) shows that $\mathrm{Na}^{+}$strongly correlates with protons from bicarbonates ions at $\delta\left({ }^{1} \mathrm{H}\right)=14.5 \mathrm{ppm}$, evidencing the presence of $\mathrm{Na}^{+}$as counter-ions. Such result is confirmed through $\left\{{ }^{23} \mathrm{Na}\right\}-{ }^{1} \mathrm{H}$ TRAPDOR experiments (Fig. S7) where a strong dephasing of the $14.5 \mathrm{ppm}$ resonance of the ${ }^{1} \mathrm{H}$ spectrum is observed after ${ }^{23} \mathrm{Na}$ irradiation. In addition, the ${ }^{1} \mathrm{H}$ resonance arising from organic species $\left(\delta\left({ }^{1} \mathrm{H}\right) \approx 2 \mathrm{ppm}\right.$, highlighted by an arrow in Fig. S7) do not display any dephasing. It has been proposed through $\mathrm{Na}$ K-edge XANES studies that the incorporation of $\mathrm{Na}+$ in biogenic calcite and aragonite is linked to substitution mechanism involves charge compensation through the creation of $\mathrm{CO}_{3}{ }^{2-}$ vacancies. ${ }^{88}$ Here, we demonstrate that, in addition to $\mathrm{Ca}^{2+}, \mathrm{Na}^{+}$are present in the disordered mineral domains of $H$. tuberculata nacre where they may balance the charge of bicarbonates. 


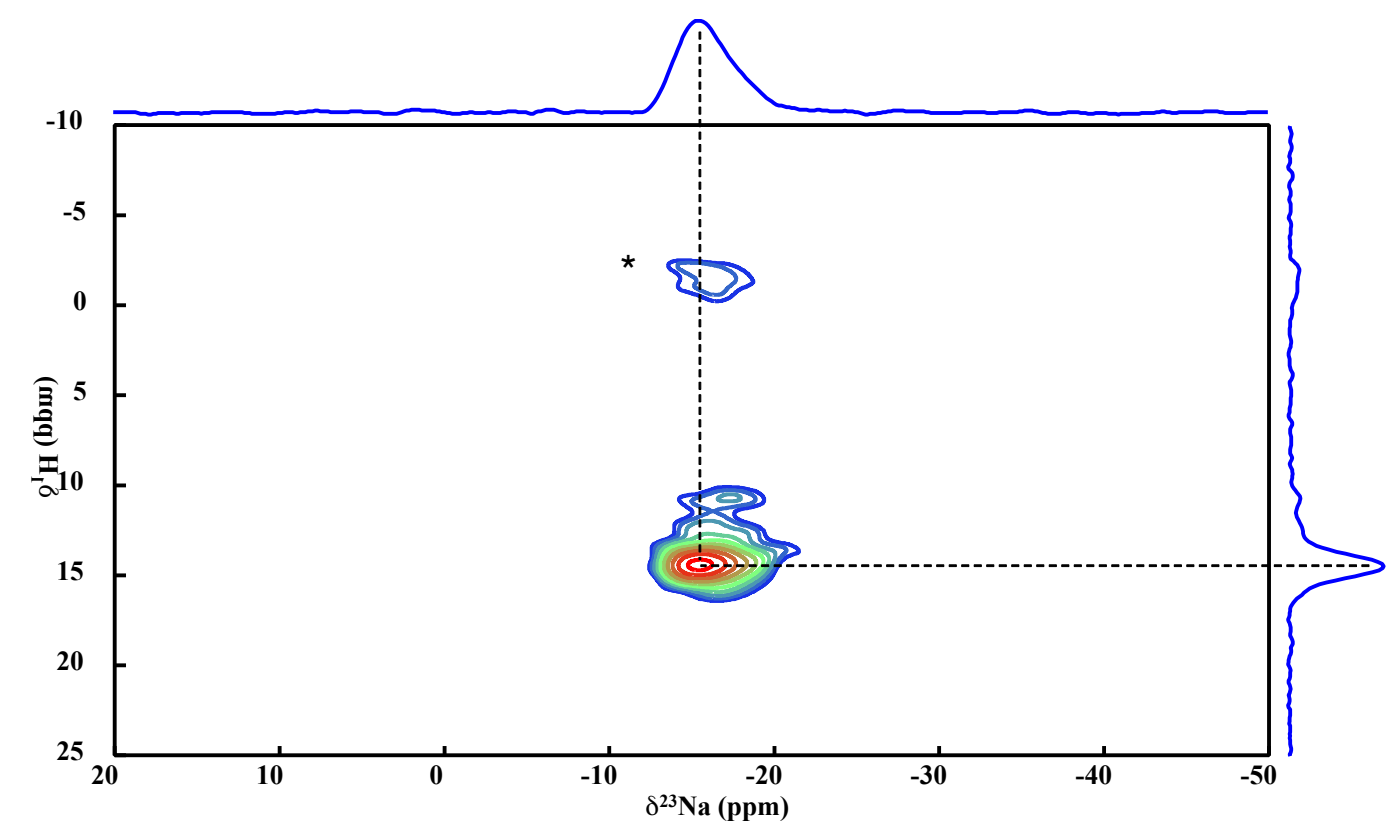

Figure 8: $2 D^{1}{ }^{1}-23 \mathrm{Na}$ HetCor NMR spectrum of Haliotis tuberculata's nacre $\left(v_{M A S}=5 \mathrm{kHz} ; \mathrm{RD}=10\right.$ $\left.s ; t_{C P}=1 \mathrm{~ms}\right) . *$ denotes spinning side band.

\section{Discussion and Conclusion}

In summary, the multinuclear ssNMR analysis highlights that disordered mineral domains are structurally more complex than an ACC phase (Fig. S8). Indeed, synthetic or biogenic ACC displays an homogeneous distribution of chemical environments around $\mathrm{CO}_{3}^{2-}$ and $\mathrm{Ca}^{2+}$ leading to a distribution of ${ }^{13} \mathrm{C}$ and ${ }^{43} \mathrm{Ca}$ chemical shifts. In contrast, the disordered mineral domains of $H$. tuberculata's nacre is structurally heterogeneous both in terms of local disorder and composition. At least, three different carbonates species, including $\mathrm{CO}_{3}^{2-}$ and $\mathrm{HCO}_{3}^{-}$, localize inside such domain. The local disorder around these ions is not homogeneous as some $\mathrm{CO}_{3}^{2-}$ have an aragonitic environment and are quite ordered whereas the chemical surrounding around $\mathrm{HCO}_{3}{ }^{-}$is highly distributed. In particular, we observe a correlation between the $\delta^{13} \mathrm{C}$ and the $\mathrm{LW}$ of interfacial carbonates: $\mathrm{LW}$ is increasing as the $\delta^{13} \mathrm{C}$ is decreasing, meaning that the disorder around carbonates increases as soon as the $\delta^{13} \mathrm{C}$ moves away from aragonite.

Concerning $\mathrm{Ca}^{2+}$, these ions exhibits surprisingly a much more disordered chemical environment (close to what is found in ACC) compared to the more structured carbonates. Noticeably, ${ }^{43} \mathrm{Ca}$ seems to be very sensitive to structural disorder compared to $1 / 2$-spins such as ${ }^{13} \mathrm{C}$. Along the line 
of such hypothesis, the case of ${ }^{31} \mathrm{P}$ and ${ }^{43} \mathrm{Ca}$ spectra of bone apatite may help to illustrate these differences in line width. Indeed, bone apatite crystalline lattice is more disordered than synthetic stoichiometric hydroxyapatite. As a consequence, the ${ }^{31} \mathrm{P}(\mathrm{I}=1 / 2)$ ssNMR spectrum of bone apatite is larger than stoichiometric apatite but still characteristic of a crystalline sample. ${ }^{94}$ However, the effect of the local disorder in the crystalline bone apatite lattice on the ${ }^{43} \mathrm{Ca}$ ssNMR spectrum is much stronger. Hence, while two ${ }^{43} \mathrm{Ca}$ resonances (i.e. corresponding to the two crystalline sites) are observed in synthetic apatite, only one broad featureless resonance is observed in bone apatite 95 similarly to what is observed here in nacre.

From all these results, the Figure 9 displays an example of a possible model of disordered mineral domains in $H$. tuberculata's nacre compatible with our results. Schematically, the distorted mineral environments can be described as follow: near the highly crystalline aragonite lattice stands (i) aragonitic carbonates polarizable by a proton-source; (ii) carbonate, still aragonitic but more distorted, are closer to the proton source composed of rigid structural water and protons from bicarbonate. Calcium ions stand close to these carbonates ensuring the electroneutrality; (iii) bicarbonates exhibit the higher molecular disorder and some of them are associated to sodium ions as counter-ions. Interestingly, bicarbonates in $H$. tuberculata nacre have been evidenced to stand near the surface of such disordered domains and to be strongly involved in the organo-mineral interface through hyperpolarized ${ }^{13} \mathrm{C}$ MAS NMR ${ }^{59}$. The absence of any strong correlation between sodium ions and water molecules (as evidenced through ${ }^{1} \mathrm{H}-23 \mathrm{Na}$ HetCor and ${ }^{23} \mathrm{Na}-{ }^{1} \mathrm{H}$ TRAPDOR NMR experiments), although a weak correlation is seen with bicarbonate ions is difficult to explain at this stage. It could be explained by a dipolar motional averaging of water molecules located at aragonite surface due to high mobility. Then, these water molecules would be trapped inside the disordered domains upon ions ordering/crystallization explaining the strong correlation observed with carbonate and the weaker correlation observed with bicarbonates.

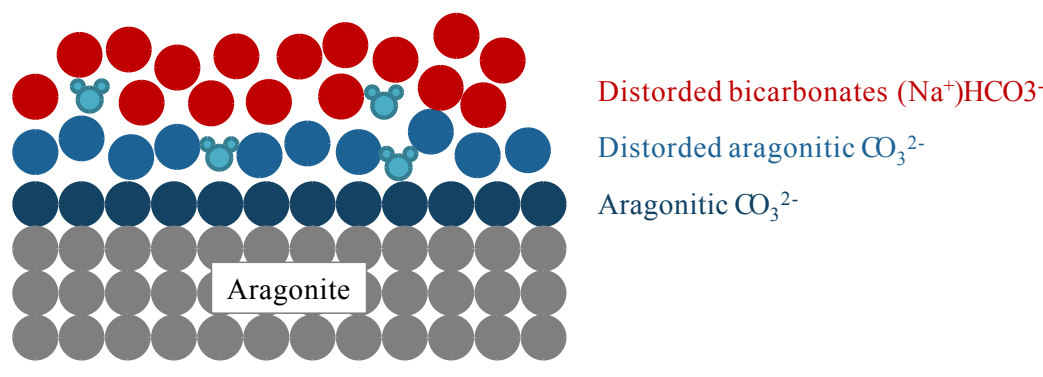


Figure 9. Schematic representation of a possible model of disordered mineral domains in $H$.

tuberculata's nacre compatible with NMR results.

As mentioned above, interestingly, the presence of a disordered mineral domain has also been evidenced in bone where the bone apatite platelets are covered by an amorphous-like hydrated surface layer. Moreover, the model of biomineral surface possessing an increasing gradient of disorder from the core to the particle surface was recently proposed for apatite crystallites formed in the presence of acidic binding peptide derived from osteonectin. ${ }^{96}$ This similar structural organization of these biominerals may result from certain common processes in the formation of biological mineralized tissues even if the mineral phases are different. Indeed, the deposition of amorphous transient mineral precursors was proposed as a first step of mineral nucleation both for bone apatite 97,98 and aragonite from nacre.61,99 The observed disordered surface domain could result from the incomplete transformation of the amorphous mineral precursors.

Our results give an unprecedented representation at the atomic scale of the ions repartition within the mineral disordered layer around aragonite tablets in nacre from the European Abalone $H$. tuberculata. We confirm the presence of sodium ions in biogenic aragonite and we demonstrate the presence of $\mathrm{Na}^{+}$, in addition to the calcium ions, and their role as counter-ions of bicarbonates within such layer. Their presence questions their role as stabilizing agents of the disordered domains by interacting with the $\mathrm{HCO}_{3}$ - ions. This finding will be helpful for further experiments dedicated to the understanding of the interface of such domains with the organic matrix and the understanding of nacre formation.

\section{Acknowledgments}

This work was supported by French state funds managed by the ANR within the Investissements d'Avenir programme under reference ANR-11-IDEX-0004-02, and more specifically within the framework of the Cluster of Excellence MATISSE led by Sorbonne Universités. W. Ajili was supported by a doctoral fellowship from the Cluster of Excellence MATISSE (Sorbonne Université, Paris, France) and the Regional Council of Brittany (France). The authors thank Imène Estève 
(IMPMC, Sorbonne Université) for the preparation of the FIB section and Guy Rodgers for fruitful discussions. High Performance Computing resources were partially provided by the EXPLOR centre hosted by the University de Lorraine. Biological samples were kindly provided by France Haliotis abalone farm (Plouguerneau, France).

\section{References}

1 Boggild, O. B. The shell structure of mollusks 1st edition, 1930.

2 Saleuddin, A. S. M.; Wilbur K. M. Shell Formation in the Mollusca. Academic Press. 1983, 235-287.

3 Watabe, N. Shell Structure in The Mollusca. Academic Press New York. 1988, p Vol 11 pp.69-104.

${ }^{4}$ Mutvei, H. Observations sur l'organisation de la couche externe du test des Haliotis (Gastropoda): un cas exceptionnel de la variabilite mineralogique et microstructurale. Bull Mus Nat Hist Nat Paris Ser 4 1985, 7(1), 73-91.

${ }^{5}$ Dauphin, Y.; Cuif, J. P.; Mutvei, H. \& Denis, A. Mineralogy, chemistry and ultrastructure of the external shell-layer in ten species of Haliotis with reference to Haliotis tuberculata (Mollusca: Archaeogastropoda). Bulletin of the Geological Institutions of the University of Uppsala 1989, 15, 7-37.

6 Lin, A. \& Meyers, M. A. Growth and structure in abalone shell. Materials Science and Engineering: A 2005, 390(1-2), 27-41.

7 Nakahara, H.; Bevelander, G.; Kakei, M. Electron Microscopic and Amino Acid Studies on the Outer and Inner Shell Layers of Haliotis Rufescens. Japanese Journal of Malacology. 1982, 41(1), 33-46.

8 Lowenstam, H. A.; Weiner, S. On Biomineralization; Oxford University Press, 1989.

9 Belcher, A. M.; Wu, X. H.; Christensen, R. J.; Hansma, P. K.; Stucky, G. D.; Morse, D. E. Control of Crystal Phase Switching and Orientation by Soluble Mollusc-Shell Proteins. Nature 1996, 381 (6577), 56-58.

10 Falini, G.; Albeck, S.; Weiner, S.; Addadi, L. Control of Aragonite or Calcite Polymorphism by Mollusk Shell Macromolecules. Science 1996, 271 (5245), 67-69.

${ }^{11}$ Marin, F.; Luquet, G. Molluscan Shell Proteins. Comptes Rendus Palevol 2004, 3 (6), 469-492.

${ }^{12}$ Schneider, A. S.; Heiland, B.; Peter, N. J.; Guth, C.; Arzt, E.; Weiss, I. M. Hierarchical SuperStructure Identified by Polarized Light Microscopy, Electron Microscopy and Nanoindentation: Implications for the Limits of Biological Control over the Growth Mode of Abalone Sea Shells. BMC Biophys. 2012, 5 (1), 19.

${ }^{13}$ Marin, F.; Luquet, G.; Marie, B. \& Medakovic, D. Molluscan shell proteins: primary structure, origin, and evolution. Current topics in developmental biology 2007, 80, 209-276.

14 Wise, S.W. Microarchitecture and mode of formation of nacre (mother of pearl) in pelecypods, gastropods and cephalopods. Eclogae Geol. Helv. 1970, 63, 775-797.

15 Nakahara, H. (1991) Nacre formation in bivalve and gastropod molluscs. In: Mechanisms and phylogeny of mineralization in biological systems (Suga, S. \& Nakahara, H., eds), Springer-Verlag, Berlin, Chapter 4.2, pp.343-350.

16 Sun, J.; Bhushan, B. Hierarchical Structure and Mechanical Properties of Nacre: A Review. RSC Adv. 2012, 2 (20), 7617-7632.

17 Heinemann, F.; Launspach, M.; Gries, K.; Fritz, M. Gastropod Nacre: Structure, Properties and Growth - Biological, Chemical and Physical Basics. Biophys. Chem. 2011, 153 (2), 126-153. 
18 Watabe, N., \& Wilbur, K. M. Influence of the organic matrix on crystal type in molluscs. Nature 1960, 188(4747), 334.

19 Bevelander, G. \& Nakahara, H. An electron microscope study of the formation of the nacreous layer in the shell of certain bivalve molluscs. Calc. Tis Res. 1969, 3, 84-92.

20 Weiner, S., \& Traub, W. X-ray diffraction study of the insoluble organic matrix of mollusk shells. FEBS letters 1980, 111(2), 311-316.

${ }^{21}$ Crenshaw, M. A. The soluble matrix from Mercenaria mercenaria shell. Biomineralization 1972, 6, 6-11.

22 Weiner, S.; Talmon, Y. \& Traub, W. Electron diffraction of mollusc shell organic matrices and their relationship to the mineral phase. International Journal of Biological Macromolecules 1983, 5(6), 325-328.

23 Kono, H. Two-dimensional magic angle spinning NMR investigation of naturally occurring chitins: precise ${ }^{1} \mathrm{H}$ and ${ }^{13} \mathrm{C}$ resonance assignment of $\mathrm{a}$-and B-chitin. Biopolymers 2004, 75, 255-263.

24 Marie, B.; Luquet, G.; Pais De Barros, J. P.; Guichard, N.; Morel, S.; Alcaraz, G.; Bollache, L. and Marin, F. The shell matrix of the unionid freshwater mussel Unio pictorum (Paleoheterodonta, Unionoida): Involvement of acidic polysaccharides from glycoproteins in nacre mineralization. The FEBS journal 2007, 274(11), 2933-2945.

${ }^{25}$ Addadi, L.; Joester, D.; Nudelman, F.; Weiner, S. Mollusk Shell Formation: A Source of New Concepts for Understanding Biomineralization Processes. Chem. - Eur. J. 2006, 12 (4), 980-987.

26 Weiner, S.; Dove, P. M. An Overview of Biomineralization Processes and the Problem of the Vital Effect. Rev. Mineral. Geochem. 2003, 54 (1), 1-29.

27 Feng, Q. L.; Cui, F. Z.; Pu, G.; Wang, R. Z.; Li, H. D. Crystal Orientation, Toughening Mechanisms and a Mimic of Nacre. Mater. Sci. Eng. C 2000, 11 (1), 19-25.

28 Checa, A. G.; Cartwright, J. H. E.; Willinger, M.-G. Mineral Bridges in Nacre. J. Struct. Biol. 2011, $176(3), 330-339$.

29 Wada, K. Crystal growth of molluscan shells. Bull. Natl. Pearl Res. Lab. 1961, 7, 703-828.

30 Wada, K. Studies on the mineralization of the calcified tissue in molluscs-X.Histochemical determination of the nature of acid mucopolysaccharide in organic crystals, Bulletin of the Japanese Society of Scientific Fisheries 1964, 30, 993-998.

31 Erben, H. \& Watabe, N. Crystal formation and growth in bivalve nacre, Nature 1974, $248,2$.

32 Gries, K.; Kröger, R.; Kübel, C.; Schowalter, M.; Fritz, M. and Rosenauer, A. Correlation of the orientation of stacked aragonite platelets in nacre and their connection via mineral bridges, Ultramicroscopy 2009, 109, 230-236

33 Olson, I. C.; Blonsky, A. Z.; Tamura, N.; Kunz, M.; Pokroy, B.; Romao, C. P.; White, M. A. and Gilbert, Pupa U.P.A. Crystal nucleation and near-epitaxial growth in nacre, J. Struct. Biol. 2013, $184,3,454-463$.

${ }^{34}$ Weiner, S.; Traub, W. Macromolecules in Mollusc Shells and Their Functions in Biomineralization. Phil Trans $R$ Soc Lond B 1984, 304 (1121), 425-434.

35 Schäffer, T. E.; lonescu-Zanetti, C.; Proksch, R.; Fritz, M.; Walters, D. A.; Almqvist, N.; Zaremba, C. M.; Belcher, A. M.; Smith, B. L.; Stucky, G. D.; et al. Does Abalone Nacre Form by Heteroepitaxial Nucleation or by Growth through Mineral Bridges? Chem. Mater. 1997, 9 (8), 1731-1740.

36 Iwata, K. Mineralization and architecture of the larval shell of Haliotis discus hannai Ino (Archaeogastropoda). Journal of the Faculty of Science, Hokkaido University 1980, Series 4. 19: 305-320. 
${ }^{37}$ Mutvei, $\mathrm{H}$. Ultrastructure of the mineral and organic components of molluscan nacreous layers. Biomineralization Research Report 1970, 2, 48-72.

38 Dauphin, Y.; Ball, A.D.; Cotte, M.; Cuif, J.P.; Meibom, A.; Salomé, M.; Susini, J. \& Williams, C.T. Structure and composition of the nacre-prisms transition in the shell of Pinctada margaritifera (Mollusca, Bivalvia). Anal. Bioanal. Chem. 2008, 390, 1659-1669.

39 Giles, R.; Manne, S.; Mann, S.; Morse, D. E.; Stucky, G. D. \& Hansma, P. K. Inorganic overgrowth of aragonite on molluscan nacre examined by atomic force microscopy. The Biological Bulletin 1995, 188(1), 8-15.

40 Manne, S.; Zaremba, C. M.; Giles, R.; Huggins, L.; Walters, D. A.; Belcher, A.; Morse, D. E.; Stucky, G. D.; Didymus J. M.; Mann S. and Hansma, P. K. Atomic force microscopy of the nacreous layer in mollusc shells. Proceedings of the Royal Society of London. Series B: Biological Sciences 1994, 256, 17-23.

${ }^{41}$ Rousseau, M.; Lopez, E.; Stempflé, P.; Brendlé, M.; Franke, L.; Guette, A.; Naslain, R.; Bourrat, X. Multiscale Structure of Sheet Nacre. Biomaterials 2005, 26 (31), 6254-6262.

42 Jingtan, S.; Fangjie, Z.; Guiyou, Z.; Hongzhong, W.; Lixing, X.; Rongqing, Z. Transformation of amorphous calcium carbonate nanoparticles into aragonite controlled by ACCBP. CrystEngComm 2016, 18, 2125-2134

${ }^{43}$ Grégoire C. Structure of the molluscan shell. In Florfin M, Scheer BT editors, Chemical Zoology, vol. II, New-York, 1972:45-102.

${ }^{44}$ Pokroy, B.; Fieramosca, J. S.; Von Dreele, R. B.; Fitch, A. N.; Caspi, E. N.; Zolotoyabko, E. Atomic Structure of Biogenic Aragonite. Chem. Mater. 2007, 19 (13), 3244-3251.

45 Niederberger, M.; Cölfen, H. Oriented Attachment and Mesocrystals: Non-Classical Crystallization Mechanisms Based on Nanoparticle Assembly. Phys. Chem. Chem. Phys. 2006, 8 (28), 3271-3287.

46 Nassif, N.; Pinna, N.; Gehrke, N.; Antonietti, M.; Jäger, C.; Cölfen, H. Amorphous Layer around Aragonite Platelets in Nacre. Proc. Natl. Acad. Sci. U. S. A. 2005, 102 (36), 12653-12655.

47 Zhang, G.; Xu, J. From Colloidal Nanoparticles to a Single Crystal: New Insights into the Formation of Nacre's Aragonite Tablets. J. Struct. Biol. 2013, 182 (1), 36-43.

48 Jäger, C.; Cölfen, H. Fine Structure of Nacre Revealed by Solid State ${ }^{13} \mathrm{C}$ and ${ }^{1 \mathrm{H}}$ NMR. CrystEngComm 2007, 9 (12), 1237-1244.

49 Wang, Y.; Euw, S. V.; Fernandes, F. M.; Cassaignon, S.; Selmane, M.; Laurent, G.; Pehau-Arnaudet, G.; Coelho, C.; Bonhomme-Coury, L.; Giraud-Guille, M.-M.; et al. Water-Mediated Structuring of Bone Apatite. Nat. Mater. 2013, 12 (12), 1144-1153.

50 Huang, S.-J.; Tsai, Y.-L.; Lee, Y.-L.; Lin, C.-P.; Chan, J. C. C. Structural Model of Rat Dentin Revisited. Chem. Mater. 2009, 21 (13), 2583-2585.

${ }^{51}$ Wu, Y.; Ackerman, J. L.; Kim, H. M.; Rey, C.; Barroug, A. \& Glimcher, M. J. Nuclear magnetic resonance spin-spin relaxation of the crystals of bone, dental enamel, and synthetic hydroxyapatites. J. Bone Miner. Res. 2002, 17(3), 472-480.

52 Nassif, N.; Gehrke, N.; Pinna, N.; Shirshova, N.; Tauer, K.; Antonietti, M. \& Cölfen, H. Synthesis of stable aragonite superstructures by a biomimetic crystallization pathway. Angew. Chem. Int. Ed. 2005, 44, 6004-6009.

53 Jäger, C.; Welzel, T.; Meyer-Zaika, W.; Epple, M. A Solid-State NMR Investigation of the Structure of Nanocrystalline Hydroxyapatite. Magn. Reson. Chem. 2006, 44 (6), 573-580.

${ }^{54}$ Kolodziejski, W. Solid-state NMR studies of bone. Top. Curr. Chem. 2005, 246, 235-270.

55 Duer, M. J.; The contribution of solid-state NMR spectroscopy to understanding biomineralization: Atomic and molecular structure of bone. J. Magn. Reson. 2015, 253, 98-110 
${ }^{56}$ Ben Shir, I.; Kababya, S.; Schmidt, A. Molecular-Level Structure-Property Relationships in Biogenic Calcium Carbonates: The Unique Insights of Solid-State NMR Spectroscopy. Isr. J. Chem. 2014, 54 (12), 74-85.

57 Jäger, C.; Cölfen, H. Fine Structure of Nacre Revealed by Solid State ${ }^{13} \mathrm{C}$ and ${ }^{1} \mathrm{H}$ NMR.

CrystEngComm 2007, 9 (12), 1237-1244.

58 Ben Shir, I.; Kababya, S.; Katz, I.; Pokroy, B.; Schmidt, A. Exposed and Buried Biomineral Interfaces in the Aragonitic Shell of Perna Canaliculus Revealed by Solid-State NMR. Chem. Mater. 2013, 25 (22), 4595-4602.

${ }^{59}$ Azaïs, T.; Von Euw, S.; Ajili, W.; Auzoux-Bordenave, S.; Bertani, P.; Gajan, D.; Emsley, L.; Nassif, N.; Lesage, A. Structural description of surfaces and interfaces in biominerals by DNP SENS. Solid State Nucl. Magn. Reson. 2019, 102, 2-11

${ }^{60}$ Auzoux-Bordenave, S.; Badou, A.; Gaume, B.; Berland, S.; Helléouet, M.-N.; Milet, C.; Huchette, S. Ultrastructure, Chemistry and Mineralogy of the Growing Shell of the European Abalone Haliotis Tuberculata. J. Struct. Biol. 2010, 171 (3), 277-290.

${ }^{61}$ Auzoux-Bordenave, S.; Brahmi, C.; Badou, A.; Rafélis, M.; Huchette, S. Shell Growth, Microstructure and Composition over the Development Cycle of the European Abalone Haliotis Tuberculata. Mar. Biol. 2015, 162, 687-697.

62 Jackson, A. P.; Vincent, J. F. V.; Turner, R. M. The Mechanical Design of Nacre. Proc R Soc Lond B 1988, 234 (1277), 415-440.

${ }^{63}$ Fritz, M.; Belcher, A. M.; Radmacher, M.; Walters, D. A.; Hansma, P. K.; Stucky, G. D.; Morse, D. E.; Mann, S. Flat Pearls from Biofabrication of Organized Composites on Inorganic Substrates. Nature 1994, 371 (6492), 49-51.

${ }^{64}$ Chateigner, D.; Hedegaard, C.; Wenk, H.-R. Mollusc Shell Microstructures and Crystallographic Textures. J. Struct. Geol. 2000, 22 (11), 1723-1735.

${ }^{65}$ Jiang, J.; Gao, M.-R.; Qiu, Y.-H.; Yu, S.-H. Gram-Scale, Low-Cost, Rapid Synthesis of Highly Stable Mg-ACC Nanoparticles and Their Long-Term Preservation. Nanoscale 2010, 2 (11), 2358-2361.

66 Wang, L.; Sondi, I.; Matijevic, E. Preparation of Uniform Needle-Like Aragonite Particles by Homogeneous Precipitation. J. Colloid Interface Sci. 1999, 218 (2), 545-553.

${ }^{67}$ Massiot, D.; Fayon, F.; Capron, M.; King, I.; Le Calvé, S.; Alonso, B.; Durand, J-O.; Bujoli, B.; Gan, Z. \& Hoatson, G. Modelling one-and two-dimensional solid-state NMR spectra. Magn. Reson. Chem. 2002, 40(1), 70-76.

68 Pickard, C. J.; Mauri, F. All-Electron Magnetic Response with Pseudopotentials: NMR Chemical Shifts. Phys. Rev. B 2001, 63 (24), 245101.

${ }_{69}$ Clark, S. J.; Segall, M. D.; Pickard, C. J.; Hasnip, P. J.; Probert, M. I. J.; Refson, K.; Payne, M. C. First Principles Methods Using CASTEP. Z. Für Krist. - Cryst. Mater. 2009, 220 (5/6), 567-570.

${ }^{70}$ Perdew, J. P.; Burke, K.; Ernzerhof, M. Generalized Gradient Approximation Made Simple. Phys. Rev. Lett. 1996, 77 (18), 3865-3868.

71 Yates, J. R.; Pickard, C. J.; Mauri, F. Calculation of NMR Chemical Shifts for Extended Systems Using Ultrasoft Pseudopotentials. Phys. Rev. B 2007, 76 (2), 024401.

72 Taga, T. Crystal Structure of $\mathrm{Na}_{2} \mathrm{CO}_{3} \cdot 10 \mathrm{H}_{2} \mathrm{O}$. Acta Crystallogr. B 1969, 25 (12), 2656-2658.

73 Sass, R. L.; Scheuerman, R. F. The Crystal Structure of Sodium Bicarbonate. Acta Crystallogr. 1962, 15 (1), 77-81.

74 Gervais, C.; Dupree, R.; Pike, K. J.; Bonhomme, C.; Profeta, M.; Pickard, C. J.; Mauri, F. Combined First-Principles Computational and Experimental Multinuclear Solid-State NMR Investigation of Amino Acids. J. Phys. Chem. A 2005, 109 (31), 6960-6969. 
${ }^{75}$ Zheng, A.; Liu, S.-B.; Deng, F. ${ }^{13}$ C Shielding Tensors of Crystalline Amino Acids and Peptides:

Theoretical Predictions Based on Periodic Structure Models. J. Comput. Chem. 2009, 30 (2), 222235.

76 Wise, S. W. Microarchitecture and Deposition of Gastropod Nacre. Science 1970, 167 (3924), 14861488.

77 Weiss, I. M.; Kaufmann, S.; Mann, K.; Fritz, M. Purification and Characterization of Perlucin and Perlustrin, Two New Proteins from the Shell of the Mollusc Haliotis Laevigata. Biochem. Biophys.

Res. Commun. 2000, 267 (1), 17-21.

78 Duer, M. J. The Contribution of Solid-State NMR Spectroscopy to Understanding Biomineralization: Atomic and Molecular Structure of Bone. J. Magn. Reson. 2015, 253, 98-110.

79 Shir, I. B.; Kababya, S.; Schmidt, A. Molecular-Level Structure-Property Relationships in Biogenic Calcium Carbonates: The Unique Insights of Solid-State NMR Spectroscopy. Isr. J. Chem. 2014, 54 (12), 74-85.

80 Nebel, H.; Epple, M. Continuous Preparation of Calcite, Aragonite and Vaterite, and of Magnesium-Substituted Amorphous Calcium Carbonate (Mg-ACC). Z. Für Anorg. Allg. Chem. 2008, 634 (8), 1439-1443.

${ }^{81}$ Agbaje, O.B.A.; Ben Shir, I.; Zax D.B.; Schmidt, A.; Jacob, D.E. Biomacromolecules within bivalve shells: is chitin abundant? Acta Biomater. 2018, 80, 176-187.

82 Gavriel, R.; Nadav-Tsubery, M.; Glick, Y.; Yarmolenko, A.; Kofman, R.; Keinan-Adamsky, K.; Berman, A.; Mass, T. and Goobes, G. The Coral Protein CARP3 Acts from a Disordered Mineral Surface Film to Divert Aragonite Crystallization in Favor of Mg-Calcite. Adv. Funct. Mater. 2018, 28, 1707321

83 Eckert, H. Structural characterization of noncrystalline solids and glasses using solid state NMR. Prog. Nucl. Magn. Reson. Spec. 1992, 24, 159-293.

84 Sen, S., Kaseman, D. C., Colas, B., Jacob, D. E., \& Clark, S. M. Hydrogen bonding induced distortion of $\mathrm{CO} 3$ units and kinetic stabilization of amorphous calcium carbonate: results from 2D ${ }^{13}$ C NMR spectroscopy. Physical Chemistry Chemical Physics 2016, 18(30), 20330-20337.

${ }^{85}$ Sevelsted, T. F., Herfort, D., \& Skibsted, J. ${ }^{13} \mathrm{C}$ chemical shift anisotropies for carbonate ions in cement minerals and the use of ${ }^{13} \mathrm{C},{ }^{27} \mathrm{Al}$ and ${ }^{29} \mathrm{Si}$ MAS NMR in studies of Portland cement including limestone additions. Cement and Concrete Research 2013, 52, 100-111.

86 Di Bitetto, A., Kervern, G., André, E., Durand, P., \& Carteret, C. Carbonate-Hydrogenocarbonate Coexistence and Dynamics in Layered Double Hydroxides. J. Phys. Chem. C 2017, 121(11), 6104-6112.

${ }^{87}$ Akiva-Tal, A.; Kababya, S.; Balazs, Y. S.; Glazer, L.; Berman, A.; Sagi, A.; Schmidt, A. In Situ Molecular NMR Picture of Bioavailable Calcium Stabilized as Amorphous $\mathrm{CaCO}_{3}$ Biomineral in Crayfish Gastroliths. Proc. Natl. Acad. Sci. 2011.

88 Gertman, R.; Ben Shir, I.; Kababya, S.; Schmidt, A. In Situ Observation of the Internal Structure and Composition of Biomineralized Emiliania Huxleyi Calcite by Solid-State NMR Spectroscopy. J. Am. Chem. Soc. 2008, 130 (40), 13425-13432.

${ }^{89}$ Albéric, M.; Caspi, E. N.; Bennet, M.; Ajili, W.; Nassif, N.; Azaïs, T.; Berner, A.; Fratzl, P.;

Zolotoyabko, E.; Bertinetti, L.; et al. Interplay between Calcite, Amorphous Calcium Carbonate, and Intracrystalline Organics in Sea Urchin Skeletal Elements. Cryst. Growth Des. 2018, 18 (4), 21892201.

90 M. Widdifield, C.; Moudrakovski, I.; L. Bryce, D. Calcium-43 Chemical Shift and Electric Field Gradient Tensor Interplay: A Sensitive Probe of Structure, Polymorphism, and Hydration. Phys. Chem. Chem. Phys. 2014, 16 (26), 13340-13359.

${ }^{91}$ Kengens et al, A.P.M. Kentgens, R. Verhagen. Advantages of double frequency sweeps in static, MAS and MQMAS NMR of spin I= 3/2 nuclei. Chem. Phys. Lett. 1999, 300, 435-443. 
92 Huang, Y.-C.; Mou, Y.; Tsai, T. W.-T.; Wu, Y.-J.; Lee, H.-K.; Huang, S.-J.; Chan, J. C. C. Calcium-43 NMR Studies of Polymorphic Transition of Calcite to Aragonite. J. Phys. Chem. B 2012, 116 (49), 14295-14301.

93 Yoshimura, T.; Tamenori, Y.; Suzuki, A.; Kawahata, H.; Iwasaki, N.; Hasegawa, H.; Nguyen, L. T.; Kuroyanagi, A.; Yamazaki, T.; Kuroda, J. \& Ohkouchi, N. Altervalent substitution of sodium for calcium in biogenic calcite and aragonite. Geochimica et Cosmochimica Acta 2017, 202, 21-38.

94 Wang, Y.; Euw, S. V.; Laurent, G.; Crevant, C.; Bonhomme-Coury, L.; Giraud-Guille, M.-M.; Babonneau, F.; Nassif, N.; Azaïs, T. Impact of Collagen Confinement vs. Ionic Substitutions on the Local Disorder in Bone and Biomimetic Apatites. Mater. Horiz. 2014, 1 (2), 224-231.

95 Xu, J.; Zhu, P.; Gan, Z.; Sahar, N.; Tecklenburg, M.; Morris, M. D.; Kohn, D. H.; Ramamoorthy, A. Natural-Abundance 43Ca Solid-State NMR Spectroscopy of Bone. J. Am. Chem. Soc. 2010, 132 (33), 11504-11509.

96 Iline-Vul, T.; Matlahov, I.; Grinblat, J.; Keinan-Adamsky, K. \& Goobes, G. Changes to the disordered phase and apatite crystallite morphology during mineralization by an acidic mineral binding peptide from osteonectin. Biomacromol. 2015, 16(9), 2656-2663.

${ }_{97}$ Mahamid, J.; Sharir, A.; Addadi, L.; Weiner, S. Amorphous Calcium Phosphate Is a Major Component of the Forming Fin Bones of Zebrafish: Indications for an Amorphous Precursor Phase. Proc. Natl. Acad. Sci. 2008.

98 Mahamid, J.; Aichmayer, B.; Shimoni, E.; Ziblat, R.; Li, C.; Siegel, S.; Paris, O.; Fratzl, P.; Weiner, S.; Addadi, L. Mapping Amorphous Calcium Phosphate Transformation into Crystalline Mineral from the Cell to the Bone in Zebrafish Fin Rays. Proc. Natl. Acad. Sci. 2010, 107 (14), 6316-6321.

${ }^{99}$ DeVol, R. T.; Sun, C.-Y.; Marcus, M. A.; Coppersmith, S. N.; Myneni, S. C. B.; Gilbert, P. U. P. A. Nanoscale Transforming Mineral Phases in Fresh Nacre. J. Am. Chem. Soc. 2015, 137 (41), 1332513333. 